\title{
Bcl-x Pre-mRNA Splicing Regulates Brain Injury after Neonatal Hypoxia-Ischemia
}

\author{
Qingli Xiao, Andria L. Ford, Jan Xu, Ping Yan, Kuang-Yung Lee, Ernesto Gonzales, Tim West, David M. Holtzman, \\ and Jin-Moo Lee \\ Hope Center for Neurological Disorders and Department of Neurology, Washington University School of Medicine, St. Louis, Missouri 63110
}

The $b c l-x$ gene appears to play a critical role in regulating apoptosis in the developing and mature CNS and following CNS injury. Two isoforms of $\mathrm{Bcl}-\mathrm{x}$ are produced as a result of alternative pre-mRNA splicing: $\mathrm{Bcl}-\mathrm{x}_{\mathrm{L}}$ (the long form) is anti-apoptotic, while Bcl- $\mathrm{x}_{\mathrm{S}}$ (short form) is pro-apoptotic. Despite the antagonistic activities of these two isoforms, little is known about how regulation of alternative splicing of $b c l-x$ may mediate neural cell apoptosis. Here, we report that apoptotic stimuli (staurosporine or C2-ceramide) reciprocally altered Bcl-x splicing in neural cells, decreasing Bcl- $\mathrm{x}_{\mathrm{L}}$ while increasing Bcl- $\mathrm{x}_{\mathrm{S}}$. Specific knockdown of Bcl- $\mathrm{x}_{\mathrm{S}}$ attenuated apoptosis. To further define regulatory elements that influenced Bcl-x splicing, a Bcl-x minigene was constructed. Deletional analysis revealed several consensus sequences within intron 2 that altered splicing. We found that the splicing factor, CUG-binding-protein-1 (CUGBP1), bound to a consensus sequence close to the Bcl- $\mathrm{x}_{\mathrm{L}} 5^{\prime}$ splice site, altering the $\mathrm{Bcl}-\mathrm{x}_{\mathrm{L}} / \mathrm{Bcl}-\mathrm{x}_{\mathrm{S}}$ ratio and influencing cell death. In vivo, neonatal hypoxia-ischemia reciprocally altered Bcl-x pre-mRNA splicing, similar to the in vitro studies. Manipulation of the splice isoforms using viral gene transfer of $\mathrm{Bcl}-\mathrm{x}_{\mathrm{S}}$ shRNA into the hippocampus of rats before neonatal hypoxia-ischemia decreased vulnerability to injury. Moreover, alterations in nuclear CUGBP1 preceded Bcl-x splicing changes. These results suggest that alternative pre-mRNA splicing may be an important regulatory mechanism for cell death after acute neurological injury and may potentially provide novel targets for intervention.

\section{Introduction}

Hypoxic-ischemic insults to the perinatal brain frequently lead to severe brain injury with resultant intellectual impairment, motor disability, and seizures at later ages. Animal studies have shown that the mechanisms leading to injury in the developing brain are distinct from those involved in adult brain injury (Back et al., 2002; McQuillen et al., 2003). Though not an exclusive injury mechanism, apoptosis appears to play a prominent role in neonatal hypoxia-ischemia (H-I), as this cascade is easily engaged after brain insults during this developmental stage (Pulera et al., 1998; Nakajima et al., 2000). A proximal and important regulator of apoptosis is the mitochondrial protein $\mathrm{Bcl}-\mathrm{x}_{\mathrm{L}}$, which is highly expressed during embryonic development in the CNS. Deletion of $b c l-x$, the gene that encodes Bcl- $x_{\mathrm{L}}$, in mice results in massive neuronal death in the brain, spinal cord, and dorsal root ganglia during late embryonic development (Motoyama et al., 1995), indicating that $b c l-x$ is important for neuronal survival. Moreover, $\mathrm{Bcl}-\mathrm{x}_{\mathrm{L}}$ overexpression attenuates brain injury caused

\footnotetext{
Received May 31, 2012; revised July 20, 2012; accepted Aug. 8, 2012.

Author contributions: Q.X., D.M.H., and J.-M.L. designed research; Q.X., A.L.F., J.X., P.Y., K.-Y.L., E.G., and T.W. performed research; Q.X., A.L.F., J.X., P.Y., K.-Y.L., T.W., D.M.H., and J.-M.L. analyzed data; Q.X., A.L.F., D.M.H., and J.-M.L. wrote the paper.

This work was supported by the National Institutes of Health Grants R01 NS48283, R01 NS67905, and P01 NS32636 (to J.M.L.), P01 NS35902 (to D.M.H.), American Heart Association Grant $0720035 Z$ (to Q.X), NIH Neuroscience Blueprint Center Core Grant P30 NS057105, and a grant from the Hope Center for Neurological Disorders.

The authors declare no competing financial interests.

Correspondence should be addressed to Dr. Jin-Moo Lee, 660 South Euclid Avenue, Campus Box 8111, St. Louis, M0 63110/ E-mail: leejm@neuro.wustl.edu.

DOI:10.1523/JNEUROSCI.2617-12.2012

Copyright $\odot 2012$ the authors $\quad 0270-6474 / 12 / 3213587-10 \$ 15.00 / 0$
}

by a variety of CNS insults, including $\mathrm{H}-\mathrm{I}$ in neonatal rodents (Parsadanian et al., 1998; Wiessner et al., 1999; Cao et al., 2002; Yin et al., 2006).

The $b c l-x$ gene generates two protein products with opposing actions as a result of alternative pre-mRNA splicing: $\mathrm{Bcl}-\mathrm{x}_{\mathrm{L}}$ (the longer form) is anti-apoptotic, while Bcl- $\mathrm{x}_{\mathrm{S}}$ (the short form) is pro-apoptotic. Recent studies in a variety of cancer cell lines have shown that $\mathrm{Bcl}-\mathrm{x}_{\mathrm{L}}$ appears to be reciprocally regulated with $\mathrm{Bcl}-\mathrm{x}_{\mathrm{S}}$ following apoptotic stimuli, suggesting that alternative premRNA splicing of Bcl-x pre-mRNA may be a critical regulator of programmed cell death. Treatment of A549 adenocarcinoma cells with the apoptosis-inducing agent ceramide resulted in increased $\mathrm{Bcl}-\mathrm{x}_{\mathrm{S}}$ and a concomitant decrease in $\mathrm{Bcl}-\mathrm{x}_{\mathrm{L}}$ mRNA (Chalfant et al., 2002). Two cis-elements (CRCE1 and CRCE2) within exon 2 were shown to be necessary for ceramide-induced splicing effects (Massiello et al., 2004), and SAP155 was identified as the splicing factor that bound to CRCE1, inducing A549 cell death (Massiello et al., 2006). Other groups have demonstrated that altering pre-mRNA splicing of $\mathrm{Bcl}-\mathrm{x}$, using antisense oligonucleotides targeted at the Bcl- $\mathrm{x}_{\mathrm{L}}$ splice site, increased susceptibility to cell death (Taylor et al., 1999; Mercatante et al., 2001; Villemaire et al., 2003). Indeed, it has been proposed that a critical ratio of $\mathrm{Bcl}-\mathrm{x}_{\mathrm{L}}$ to $\mathrm{Bcl}-\mathrm{x}_{\mathrm{S}}$ is required to maintain cell survival (Minn et al., 1996).

While several studies have investigated Bcl-x pre-mRNA splicing in vitro using cell lines, few have explored its role in vivo in apoptosis or other pathological models of injury. Moreover, there are no studies that have demonstrated a requirement for endogenous $\mathrm{Bcl}-\mathrm{x}_{\mathrm{S}}$ expression in cell death. In this study, we 
sought to determine whether the regulation of Bcl-x alternative pre-mRNA splicing was an important mechanism of neural cell death following neonatal $\mathrm{H}-\mathrm{I}$.

\section{Materials and Methods}

Cell culture and death assessment. Rat oligodendrocyte progenitor (OP) cells were cultured as described previously (Zhang et al., 1999), with slight modifications. The cells were grown in progenitor medium (69\% DMEM/F-12/ HEPES containing N1 supplement, $10 \mu \mathrm{g} / \mathrm{ml}$ insulin, $20 \mathrm{~nm}$ progesterone, 100 units penicillinstreptomycin, $30 \%$ conditioned medium from B104 cells, and 1\% FBS) and plated on $100 \mathrm{~mm}$ culture dishes precoated with poly-L-lysine. Disaggregated oligosphere cells displayed bipolar or tripolar morphology. OP cells were maintained in growth medium and treated with various concentrations $(0-100 \mu \mathrm{M})$ of C2-ceramide (Biomol) for varying times. Cell viability was assessed by lactate dehydrogenase $(\mathrm{LDH})$ and the 3-(4,5-dimethylthiazol-2-yl)-2,5-diphenyl-tetrazolium bromide (MTT) assay as described previously (Xu et al., 2000). For DNA laddering, OP cells were homogenized and incubated in a lysis buffer containing RNase A and proteinase $\mathrm{K}$ overnight at $37^{\circ} \mathrm{C}$. After extraction, DNA pellets were dissolved in Tris-EDTA buffer and electrophoresed and visualized by UV light. Caspase activity was measured using a colorimetric assay kit, CaspACE assay system (Promega).

Pure neuronal cultures were prepared from the cortices of embryonic day 15 (E15) mice. Cortices were collected, digested with $0.25 \%$ trypsin, triturated, then plated in Neurobasal medium (Invitrogen) supplemented with B27 and $25 \mu \mathrm{M}$ glutamate. Cultures were kept at $37^{\circ} \mathrm{C}$ in a humidified incubator with $5 \% \mathrm{CO}_{2}$. Oxygen-glucose deprivation was performed as described previously (Xu et al., 2000). Briefly, cortical neurons were transferred into a temperature-controlled $\left(37 \pm 1^{\circ} \mathrm{C}\right)$ anaerobic chamber containing a gas mixture composed of $5 \% \mathrm{CO}_{2}, 10 \% \mathrm{H}_{2}, 85 \% \mathrm{~N}_{2}$, and $0.1 \% \mathrm{O}_{2}$. The cultures were washed three times with deoxygenated glucose-free HBSS and then kept in the same medium in the hypoxia chamber for 90 min followed by reoxygenation in a normoxic incubator under $5 \% \mathrm{CO}_{2} / 95 \%$ air for 3-24 h. Cells exposed to HBSS in a normoxic incubator served as a control.

Construction of minigene and splicing factor expression vectors. The minigenes were constructed by amplifying regions of the $b c l-x$ gene from rat genomic DNA by PCR using primers containing unique NheI, EcoRI, BglII, and XhoI restriction sites to allow replacement of segments of the minigene as cassettes. Briefly, the $2.6 \mathrm{~kb}$ fragment of $b c l$ - $x$ containing $3^{\prime}$-end of exon 1 , intron 1 , exon 2 and $5^{\prime}$-end of intron 2 was generated using a forward primer: Nf, $5^{\prime}$-ATTCCGCTAGCCTGCCTA CCAGGTC- ${ }^{\prime}$, and a reverse primer: Er, 5'-CTGGAATTCTGCCCCTCC TATAATCAGC-3' (restriction sites are underlined). Another $0.5 \mathrm{~kb}$ fragment of $b c l$ - $x$ containing $3^{\prime}$-end of intron 2 and $5^{\prime}$-end of exon 3 was generated by forward primer: Ef, $5^{\prime}$-AGAAGAATTCTCTGTCTGAA AGTCC-3', and reverse primer:Xr, 5' -AGGCTCGAGCGGTTGAAACG CTCCTGGC- $3^{\prime}$. Both of the aforementioned fragments were ligated and

E isoforms.
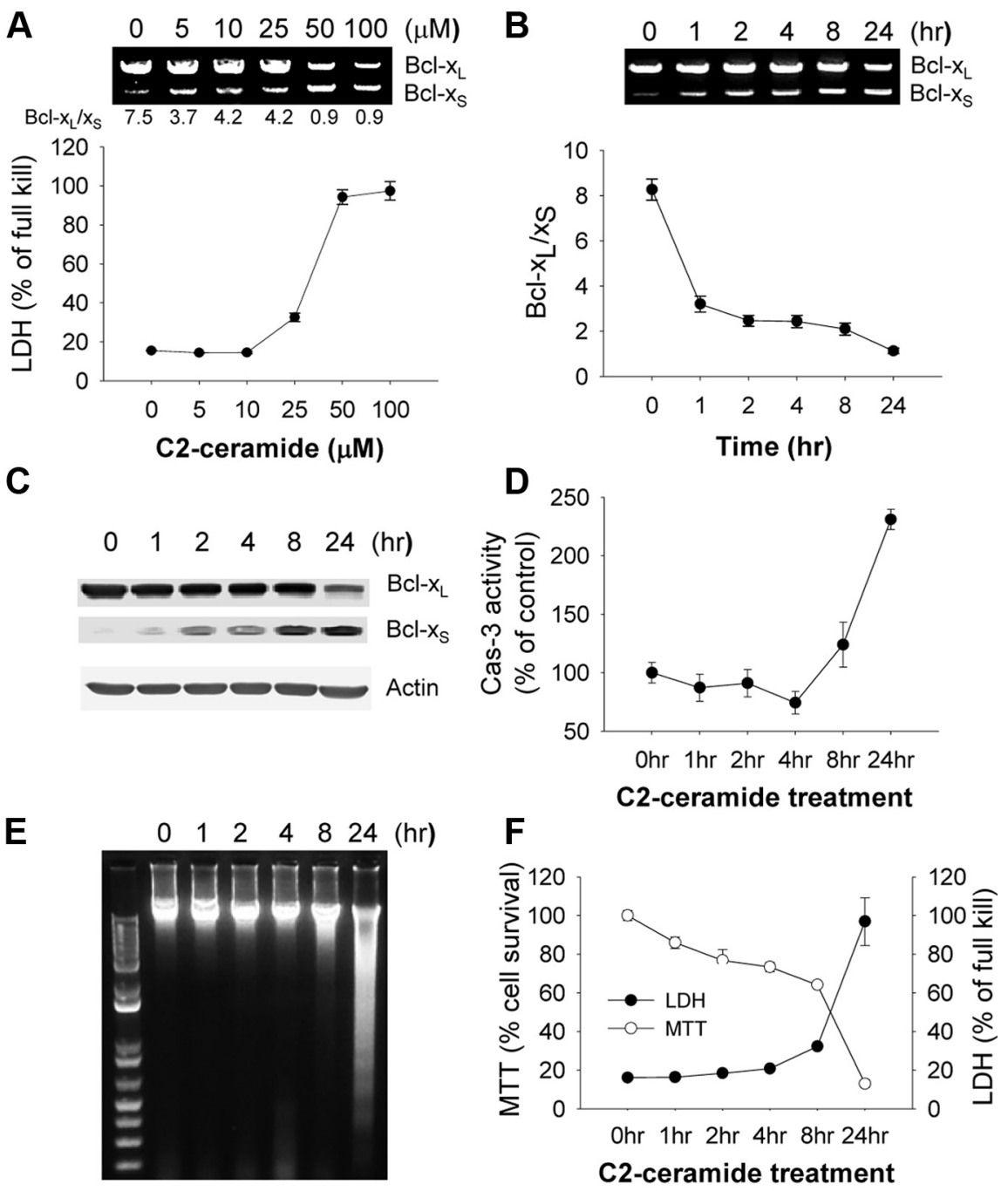

C2-ceramide treatment

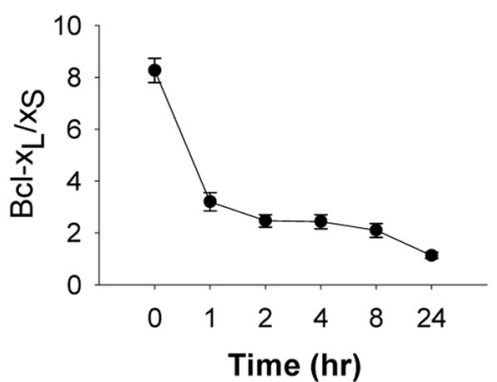

C2-ceramide treatment

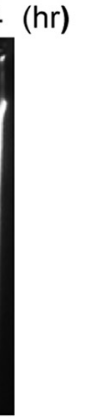

Cortical neurons

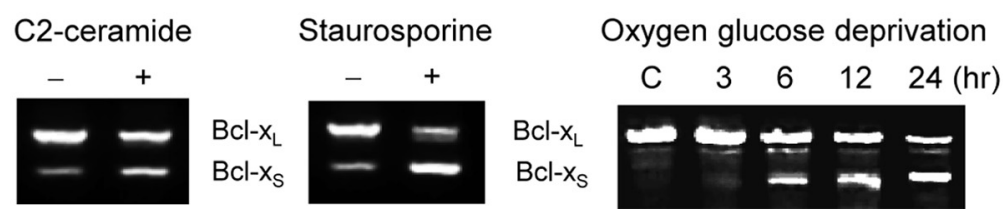

Figure 1. Changes in $\mathrm{BCl}-\mathrm{x}$ alternative splicing during apoptosis. $\boldsymbol{A}$, Oligodendrocyte precursor (OP) cells were treated with varying concentrations of $\mathrm{C} 2$-ceramide as indicated for $24 \mathrm{~h}$. Total RNA was extracted and analyzed by RT-PCR for alternative splicing of $\mathrm{BCl}-\mathrm{x}$ (noted below the gels are the $\mathrm{BCl}-\mathrm{x}_{\mathrm{L}} / \mathrm{BCl}-\mathrm{x}_{S}$ ratios). The bottom graphs show cell death by $\mathrm{LDH}$ release. $B, 0 \mathrm{P}$ cells were treated with $50 \mu \mathrm{M}$ C2-ceramide for varying times as indicated. Total RNA was extracted and analyzed by RT-PCR for alternative splicing of $\mathrm{BCl}-\mathrm{x}_{\text {, and }} \mathrm{BCl}-\mathrm{x}_{\mathrm{L}} / \mathrm{BCl}-\mathrm{x}_{S}$ ratios were quantified. $\mathbf{C}-\boldsymbol{F}, \mathrm{OP}$ cells were treated with $50 \mu \mathrm{m}$ (2-ceramide for varying times and immunoblotted for $B C l-x_{L}$ and $B C l-x_{S}(\boldsymbol{C})$, assayed for caspase- 3 activity $(\boldsymbol{D})$, DNA fragmentation $(\boldsymbol{E})$, and cell survival (MTT) and death (LDH) $(\boldsymbol{F})$. Data were expressed as mean \pm SE of three independent experiments. $\mathbf{G}$, Cortical neurons were treated with $40 \mu \mathrm{m}$ C2-ceramide or $100 \mathrm{~nm}$ staurosporine for $24 \mathrm{~h}$ or oxygen glucose deprivation for $90 \mathrm{~min}$, followed by reoxygenation for varying times (3-24 h as indicated). Shown are RT-PCR products showing reciprocal changes in BCl-x splice

inserted between the NheI and XhoI sites of pcDNA3.1 vector (Invitrogen), which contains the CMV promoter. Intron 2 deleted constructs were generated by PCR using the common forward primer Nf and following reverse primers: D1 (5'-GGAGAATTCGCTACTCTCCTAGGT T-3'), D2 (5'-AGCCAGAATTCAAAATACAGGTTCC-3'), D3 (5'-CC TGAATTCTCGATATCTTCAACAAC-3'), D4 (5'-AGGGAATTCCAC AGAGGAGAGACACAC-3'), D5 (5'-GGCGGATTCACAAGGGGCGT GGTTCT-3'). For U/G motif truncated construct, the upstream fragment was produced by $\mathrm{Nf}$ and a reverse primer Bgr, $5^{\prime}$-CTGAGATC 
TGGGGCGTGGTTC-3'. The downstream fragment was generated by $\mathrm{Xr}$ and a forward primer Bgf, 5'-CTTAGATCTCTCTTCCTCTGT-3'. The above two PCR fragments were ligated and cloned into pcDNA3.1 digested with NheI and XhoI. Site-directed mutagenesis of bcl-x minigene was performed using the GeneTailor mutagenesis kit (Invitrogen) and the following primer: $5^{\prime}$-CCTTGACTGTCCGCCCCTTGACTGTC TCTCCTCT- $3^{\prime}$. cDNA sequence of the CUG-binding protein CUGBP1 (NM_006560) was PCR amplified using a forward primer: 5' - CTCAGC TAGCAGAAAATGAACGGCAC- ${ }^{\prime}$ ' , and a reverse primer: $5^{\prime}$-CAGAAT TCAGCACGCTCAGTAGGGCT-3' and subcloned into pcDNA3.1 vector with BamHI and EcoRI restriction sites. All constructs were confirmed by sequence analysis.

Cell transfection and RT-PCR. Cells were transfected with the minigene with or without a CUGBP1 expression vector using Lipofectamine 2000 (Invitrogen). After 36-48 h, transfected cells were washed with ice-cold PBS and harvested. Cells or frozen brain tissues were homogenized and total RNA was isolated using TRI reagent (Molecular Research Center) according to the manufacturer's protocol. Two micrograms of total RNA was reversetranscribed with 200 units of reverse transcriptase (Promega) and $0.5 \mu \mathrm{g}$ of oligo $(\mathrm{dT})_{15}$ in a total reaction volume of $20 \mu \mathrm{l}$ under the conditions provided by the manufacturer's protocol. To assess endogenous Bcl-x expression, a PCR with $5^{\prime}$-TTGGACAATGGACTGGTTGA-3' (forward) and 5' CGGCTCTCGGGTGCTGTATTGTTC-3' (reverse) was performed. To measure the level of minigene-derived mRNA isoforms, the Bcl-x exon 2 forward primer (5'-AGTTTGGATGCGCGGGAGGTAATC-3') and pcDNA3.1 reverse primer BGH Rev (5' -TAGAAGGCACAGTCGAGG$3^{\prime}$ ) were used. PCR products were electrophoretically separated, and the $\mathrm{Bcl}-\mathrm{x}_{\mathrm{L}} / \mathrm{Bcl}-\mathrm{x}_{\mathrm{S}}$ mRNA ratio was calculated.

RNA interference. For knockdown of $\mathrm{Bcl}-\mathrm{x}_{\mathrm{S}}$, the paired $\mathrm{Bcl}-\mathrm{x}_{\mathrm{S}}$ shRNA sequence in pSIREN-RetroQ-ZsGreen vector (Clontech) was as follows: 5' -gatccGGAGCTTTGAACAGGACACTTTCTTCCTGTCAAAAGTGT CCTGTTCAAAGCTCCTTTTTTACGCGTg-3' and 5' -aattcACGCGTA AAAAAGGAGCTTTGAACAGGACACTTTTGACAGGAAGAAAGTGTC CTGTTCAAAGCTCCg-3'.

A complementary pair of scrambled oligonucleotides was used as control. Two siRNA sequences (synthesized by Integrated DNA Technologies) were used to target rat CUGBP1: si-1 sense sequence (5'-CCAGAUCUUGAUGC UAUCAdTdT- $3^{\prime}$ ) and antisense sequence ( $5^{\prime}$-UGAUAGCAUCAAGAUC UGGdTdT- ${ }^{\prime}$ ); si-2 sensesequence (5'-UGUAACAAAACAGCACCCUdTd T- $3^{\prime}$ ) and antisense sequence ( $5^{\prime}$-AGGGUGCUGUUUUGUUACAdTdT$\left.3^{\prime}\right)$. Duplex siRNA was transfected into OP cells at $200 \mathrm{~nm}$ using Lipofectamine 2000 (Invitrogen). RNA or protein was extracted $48 \mathrm{~h}$ after transfection.

Cell fractionation and immunoblotting. Nuclear and cytosolic protein extracts were prepared as described (Xu et al., 1997; Yin et al., 2002). Briefly, tissue or cells were harvested and resuspended in 5 volumes of buffer A (20 mm HEPES, 1.5 mm $\mathrm{MgCl}_{2}, 10 \mathrm{~mm} \mathrm{KCl}, 1$ mM EDTA, $1 \mathrm{~mm}$ EGTA, $250 \mathrm{~mm}$ sucrose, $0.1 \mathrm{~mm}$ PMSF, $1 \mathrm{~mm}$ DTT, and $1 \times$ protease inhibitor cocktail, $\mathrm{pH}$ 7.9). After $10 \mathrm{~min}$ on ice, cells were homogenized and centrifuged at $750 \times g$ for $15 \mathrm{~min}$ at $4^{\circ} \mathrm{C}$; the supernatant (cytosolic extracts) was collected and subjected to centrifugation at $15,000 \times g$ for $30 \mathrm{~min}$ to remove cellular debris. The nuclear pellet was washed three times with the same lysis buffer, resuspended in $45 \mu \mathrm{l}$ of buffer B $(20 \mathrm{~mm}$ HEPES, $1.5 \mathrm{~mm} \mathrm{MgCl}_{2}$, $20 \mathrm{~mm} \mathrm{KCl,} 0.2$ mM EDTA, 0.5 mм DTT, $0.2 \mathrm{~mm}$ PMSF, $1 \times$ protease, and phosphatase inhibitor cocktail, $\mathrm{pH} 7.9$ ), and 15 $\mu$ l of buffer C (20 mM HEPES, 1.2 M KCl, 0.2 mm EDTA, 0.5 mm DTT, 0.2 mM PMSF, $1 \times$ protease, and phosphatase inhibitor cocktail, $\mathrm{pH} 7.9$ ) was added. Samples were placed on ice for $30 \mathrm{~min}$, centrifuged at $15,000 \times \mathrm{g}$; supernatants (nuclear protein) were stored at $-80^{\circ} \mathrm{C}$. Five micrograms of nuclear proteins and $20-60 \mu \mathrm{g}$ of cytosolic or total proteins were subjected to SDS-PAGE and transferred to PVDF membranes for detecting proteins using the following antibodies: $\mathrm{Bcl}-\mathrm{x}$ (GenScript), CUGBP1 (Novus Biologicals), caspase-3 (Cell Signaling Technology), and actin (Sigma).

Electrophoretic mobility shift assay and UV cross-linking analysis. An RNA oligo containing U/G motif, 5'-CUUGUGUGUCCGCCCCUUGUGUG$3^{\prime}$, was labeled with $\left[\gamma_{-}{ }^{32} \mathrm{P}\right]$ ATP (PerkinElmer) by T4 polynucleotide kinase (Promega). RNA-protein binding was carried out at room temperature in 20 $\mu$ l of buffer (10 mм HEPES, pH 7.9, 5 mм MgCl2, 40 mм KCl, 1 mм DTT, 5
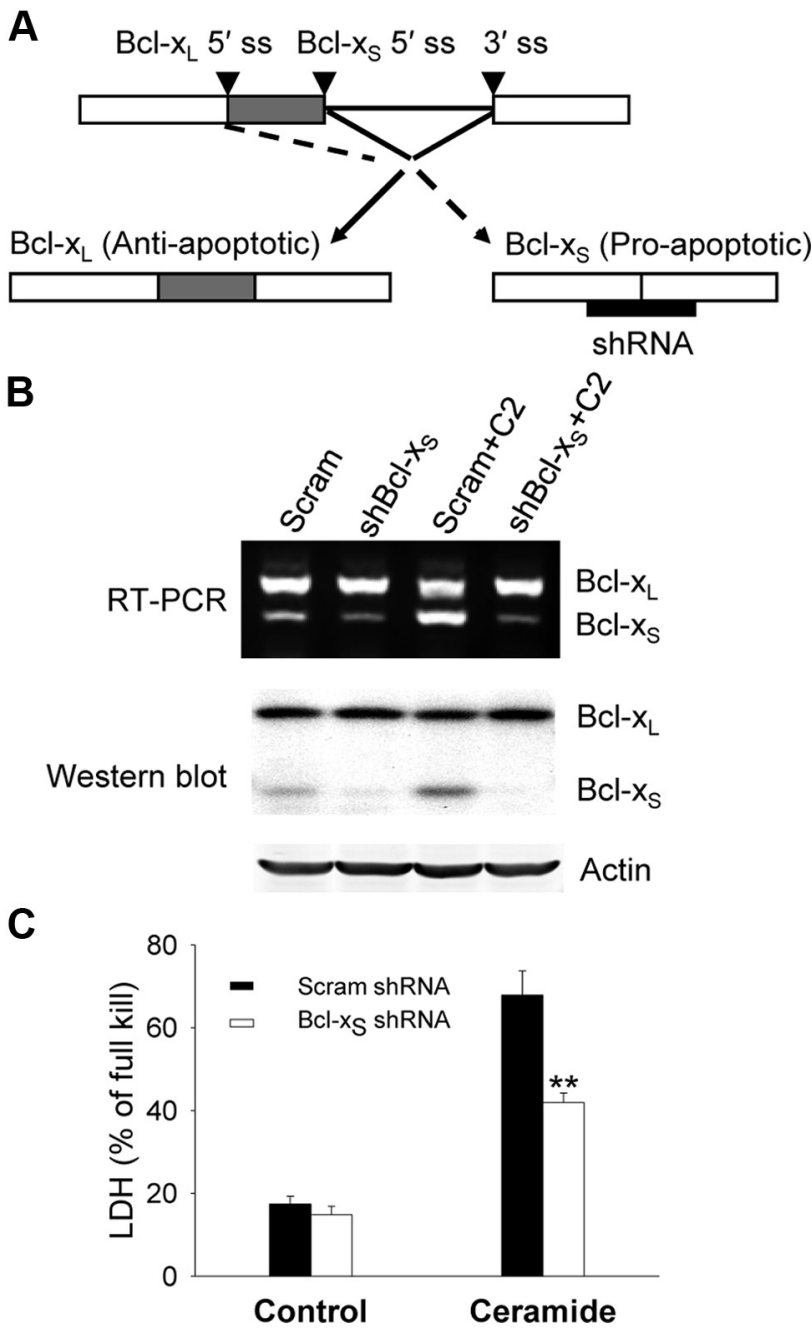

Figure 2. $\quad B C l-x_{S}$ knockdown attenuates apoptosis. $A$, Diagram shows $B C l-x$ pre-mRNA with mRNA isoforms and shRNA specifically targeted at $\mathrm{BCl}-\mathrm{x}_{\mathrm{S}} . \mathrm{OP}$ cells were infected with a retroviral vector expressing $\mathrm{BCl}-\mathrm{x}_{5}$ shRNA or scramble shRNA for $48 \mathrm{~h}$ and then treated with $\mathrm{C2}$-ceramide $(50 \mu \mathrm{M})$ for $16 \mathrm{~h}$ as described in Materials and Methods. ss, splice site. $\boldsymbol{B}, \mathrm{RT}$-PCR was performed to analyze alternatively spliced $B C l-x$ isoforms (top), and total proteins were extracted and analyzed by Western blot for $B C-x_{L}$ and $B C l-x_{S}$ (bottom). $C$, Cell death was assessed by LDH assay and expressed as mean \pm SE of three independent experiments. ${ }^{* *} p<0.01$ compared to scramble shRNA-treated OP cells.

$\mu \mathrm{g}$ of nuclear proteins) for $30 \mathrm{~min}$. Heparin was added to a final concentration of $5 \mu \mathrm{g} / \mu \mathrm{l}$. For competition experiments, unlabeled cold RNA oligo at 50 -fold molar excess was added $10 \mathrm{~min}$ before the addition of the radiolabeled probe. To identify specific proteins in the electrophoretic mobility shift assay (EMSA) complex, nuclear extracts were incubated with $2 \mu \mathrm{g}$ of antibody for $15 \mathrm{~min}$ before addition of labeled probe. After incubation with the labeled probe for an additional $30 \mathrm{~min}$, samples were subjected to native $6 \%$ PAGE. For UV cross-linking, the RNA-protein binding mixture was UV irradiated using a Spectrolinker XL-1000 UV Crosslinker (Fisher Scientific) for $30 \mathrm{~min}$ and then resolved using 10\% SDS-PAGE.

Animal models. Animal care and surgical procedures were approved by the Animal Studies Committee of Washington University School of Medicine (St. Louis, MO) in accordance with guidelines of the US National Institutes of Health. Pregnant Sprague Dawley dams were obtained from Charles River at embryonic day 15. Rat pups of both sexes were subjected to unilateral carotid ligation on postnatal day 7 (P7), followed by hypoxia as described previously (Han et al., 2002). Briefly, under halothane anesthesia the left carotid artery was exposed through an incision in the neck and cauterized. The incision was closed with skin glue and the pups were allowed to recover from anesthesia in a $37^{\circ} \mathrm{C}$ chamber. 
The pups were returned to the dam for $2 \mathrm{~h}$ for refeeding and recovery after which they were placed in chambers kept at $37^{\circ} \mathrm{C}$ through which humidified $8 \%$ oxygen (balance nitrogen) flowed. After $2.5 \mathrm{~h}$ of hypoxia, the pups were returned to the dam. At various time points (3, 6,12 , and $24 \mathrm{~h}$ ) after the end of the hypoxia, animals were killed and perfused with PBS. The hippocampus and cortex were dissected on ice and immediately frozen on dry ice.

Lentiviral vector production and hippocampal injection. The above mentioned $\mathrm{Bcl}-\mathrm{x}_{\mathrm{S}}$ shRNA or control shRNA was inserted into pRRLsinU6cass-PGK-EGFPppt plasmid (provided by Mingjie Li, Hope Center for Neurological Disorders viral core, Washington University School of Medicine) with AarI sites. shRNA and EGFP were driven by human U6 and PGK promoter, respectively. Lentiviral vectors (LVs) were generated by transfection of $293 \mathrm{~T}$ cells by using the four-plasmid system (LV plasmid constructs: pMDLgpRRE, pCMV-G, and pRSV-rev). Culture supernatants were harvested $48 \mathrm{~h}$ after transfection, passed through a $0.45 \mu \mathrm{m}$ filter, concentrated by ultracentrifugation through a $20 \%$ sucrose cushion, and stored at $-80^{\circ} \mathrm{C}$. Vector titers were determined by transduction of HT1080 cells and assayed for EGFP expression using flow cytometry. Pups at $\mathrm{P} 0$ were rested on a bed of ice for anesthetization before being placed in a modified stereotaxic holder. Two microliters of lentiviral vectors $\left(1 \times 10^{6}\right.$ infectious particles $)$ were injected into left hippocampus using the following coordinates: anteroposterior, $1.6 \mathrm{~mm}$; lateral, $-1.4 \mathrm{~mm}$; and ventral, $-2.4 \mathrm{~mm}$. $\mathrm{H}-\mathrm{I}$ was performed at $\mathrm{P} 7$.

Histology. One week after $\mathrm{H}-\mathrm{I}$, animals were perfused with PBS followed by $4 \%$ paraformaldehyde. The brains were removed, postfixed overnight, cryoprotected in PBS containing $30 \%$ sucrose at $4^{\circ} \mathrm{C}$ until submerged, and then embedded and frozen in OCT compound. Twenty-five micrometer coronal sections were cut on a freezing-sliding microtome and mounted on slides. Sections were stained with cresyl violet as described previously (Holtzman et al., 1996). Eight corresponding sections for each animal were scanned using a NanoZoomer highresolution whole-slide scanner (Hamamatsu), and the volume of hippocampus and cortex were calculated. The percent volume loss in the lesioned versus the unlesioned hemisphere was determined. Brain sections that strongly expressed EGFP in the hippocampus were selected for analysis.

Immunostaining. Fixed cells or brain sections were washed with PBS and permeabilized with $0.3 \%$ Triton X-100 in PBS for 20 min. Cells or sections were incubated with anti-monoclonal CUGBP1 antibody overnight at $4^{\circ} \mathrm{C}$ and then with goat anti-mouse secondary antibody (Alexa Fluor 488, Invitrogen) for $1 \mathrm{~h}$. For double labeling, terminal deoxynucleotidyl transferase-mediated dUTP nick end-labeling (TUNEL) assay (Millipore Bioscience Research Reagents) was performed to evaluate cell death followed by immunofluorescence staining with CUGBP1 antibody and Cy3-conjugated goat anti-mouse secondary antibody. Slides were mounted in Vectashield with DAPI (Vector Laboratories) and examined with a fluorescent microscope (Zeiss).

Statistical analysis. Values were expressed as mean \pm SE. Differences between two groups were analyzed by Student's $t$ test, and more than two groups were analyzed by one-way ANOVA followed by post hoc Tukey's test.

A

B

$B \mathrm{BCl}-\mathrm{x}_{\mathrm{L}} 5^{\prime} \mathrm{sS}$

D

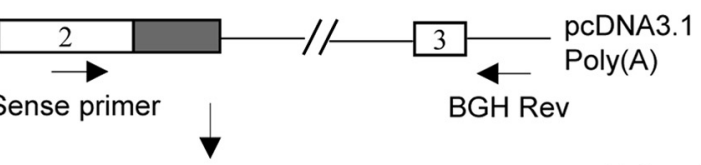

Minigene-specific RT-PCR products

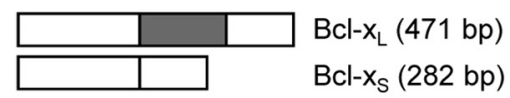

HeLa C6
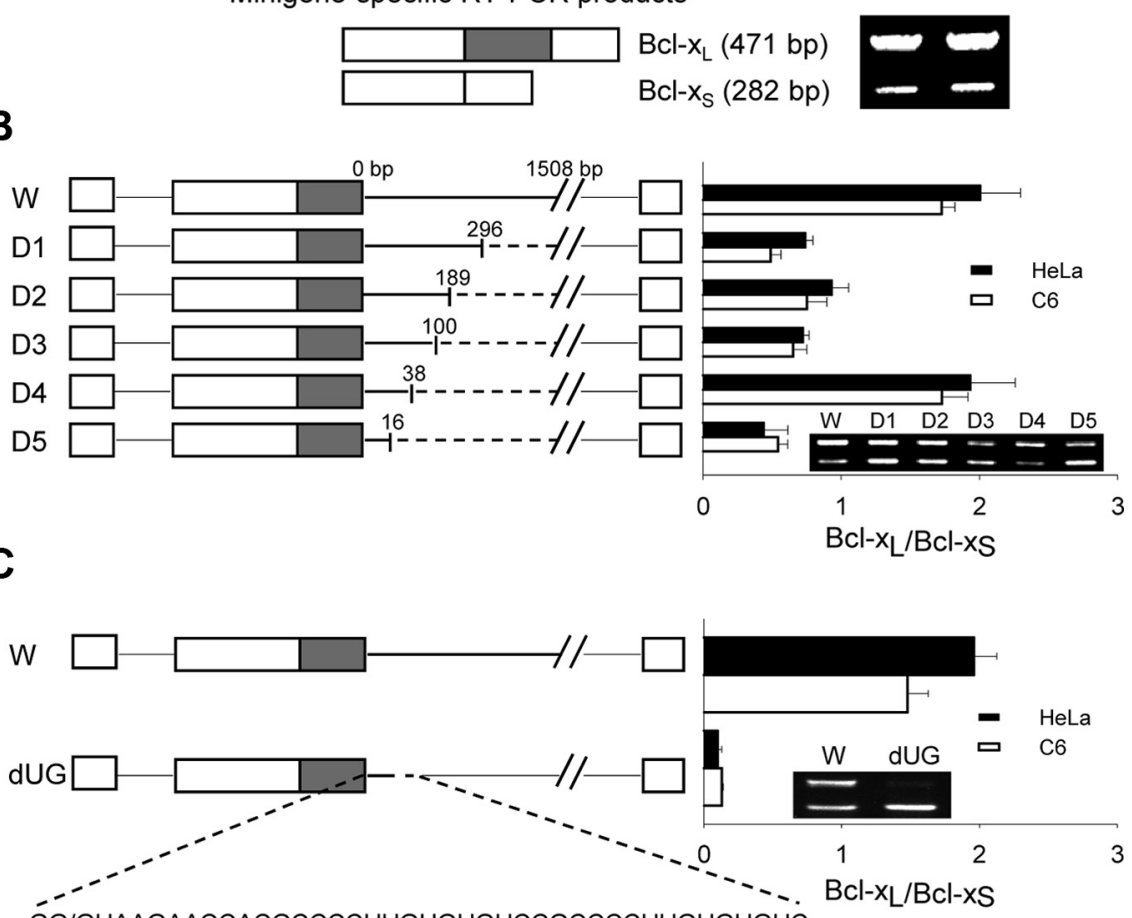

ǴG/GUAAGAACCACGCCCCUUGUGUGUCCGCCCCUUGUGUGUC

Deletion region

Wild type: UUGUGUGUCCGCCCCUUGUGUGUCU
M1:
MUGACUGUCCGCCCCUUGUGUGUCU
UUGACUGUCCGCCCCUUGACUGUCU

HeLa

C6

W $\quad$ M1 $M 2$

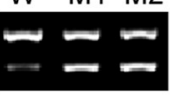

W $\mathrm{M} 1 \mathrm{M} 2$

$\mathrm{Bcl}-\mathrm{x}_{\mathrm{L}} / \mathrm{Bcl}-\mathrm{x}_{\mathrm{S}} \quad 3.6 \quad 1.3 \quad 0.9$

$\begin{array}{lll}3.9 & 1.2 & 0.9\end{array}$

Figure 3. UG rich elements modulate alternative splicing of $B C l-x . A$, Shown is the structure of the $B C l-x$ minigene construct with positions of the primers used to amplify minigene-specific mRNA products. The figure also depicts the PCR fragments obtained (WC-x minigene-transfected HeLa and C6 glioma cells. B, Wild-type (W) and truncated minigenes (D1-D5) shown on the left wnstream of the $B C l-x_{L} 5^{\prime}$ splice site (ss). C, The wild-type (W) and UG motif-deleted minigenes (22 bp deletion, dUG) alters the resulted in a decrease of $B C l-x_{L} / B C l-x_{S}$ ratios. Data were expressed as mean $\pm S E$ from three independent experiments.

\section{Results}

Bcl-x pre-mRNA splicing is a critical regulatory process in neural cell apoptosis

We have previously demonstrated that ceramide, a lipid second messenger implicated in cell death pathways, induces apoptosis in OP cells (Lee et al., 2004), which are particularly vulnerable to hypoxic-ischemic brain injury in the neonatal period (Back et al., 2002). To determine whether alternative splicing of Bcl-x premRNA is an important regulatory process in OP cell death, cells treated with C2-ceramide (C2) for $24 \mathrm{~h}$, were assessed for Bcl- $\mathrm{x}_{\mathrm{L}}$ and $\mathrm{Bcl}-\mathrm{x}_{\mathrm{S}}$ mRNAs and cell death. $\mathrm{C} 2$ induced a dose-dependent alteration in $\mathrm{Bcl}-\mathrm{x}$ mRNA isoforms; changes in $\mathrm{Bcl}-\mathrm{x}_{\mathrm{L}} / \mathrm{Bcl}-\mathrm{x}_{\mathrm{S}}$ ratios occurred at lower concentrations of $\mathrm{C} 2$ than that which induced cell death (LDH release, Fig. $1 A$ ). Similar changes in $\mathrm{Bcl}-\mathrm{x}$ 


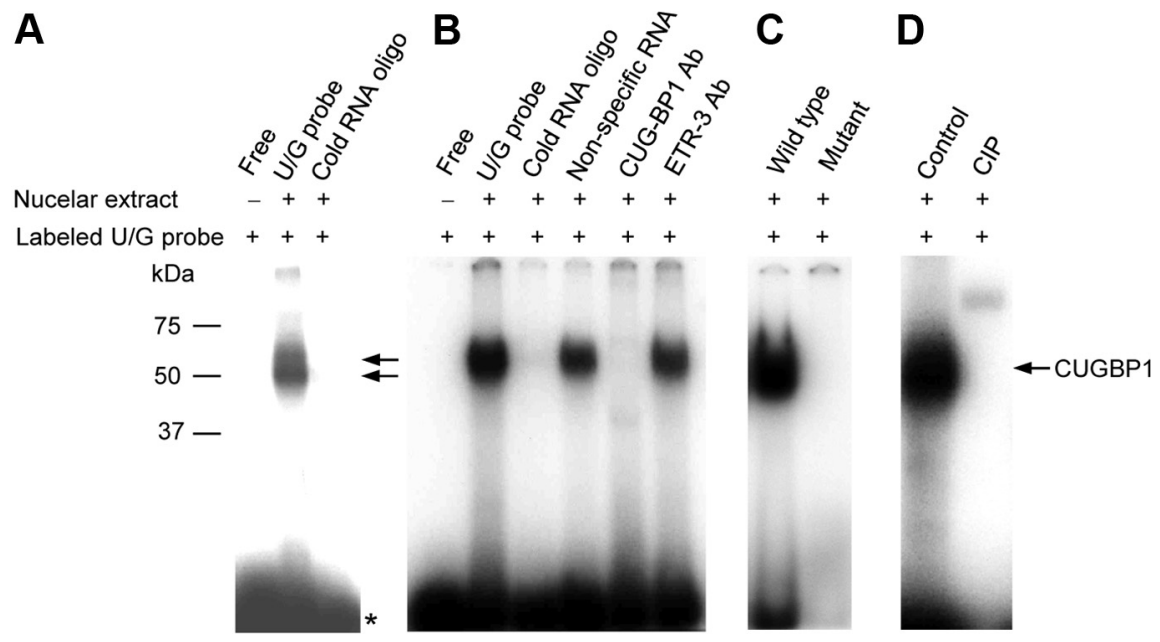

Figure 4. CUGBP1 binds to the UG-rich elements of BCl-x pre-mRNA. Five micrograms of nuclear extracts were prepared from OP cells and subjected to EMSA by reacting with a ${ }^{32}$-labeled UG rich RNA probe. Fiftyfold excess, unlabeled, nonspecific RNA or specific cold RNA samples were included to show specificity of the RNA-protein complex. $A, B, U V$ cross-linking (as described in Materials and Methods) was performed to analyze the molecular weight of trans-acting factor bound to UG probe $(\boldsymbol{A}$, star $(\star)$ indicates free probe). (UGBP1, but not ETR-3 antibodies eliminated the binding complex (B). C, A mutant probe (UG $>A C$, similar to that used in Fig. 3D) does not form the complex. D, Abrogation of binding is shown when nuclear extracts were treated with calf intestinal alkaline phosphatase (CIP).

protein isoforms were also observed (Fig. 1C). A time course of cells treated with $50 \mu \mathrm{M} \mathrm{C} 2$ revealed that Bcl-x splicing changes occurred early (within $1 \mathrm{~h}$; Fig. $1 B$ ) compared to caspase- 3 activation (first detected $8 \mathrm{~h}$ after treatment; Fig. $1 D$ ), DNA laddering $(24 \mathrm{~h}$; Fig. $1 E)$, and cell death ( 24 h; Fig. $1 F)$. Similar changes in splicing were observed in OP cells treated with the general protein kinase inhibitor staurosporine, and both apoptotic stimuli altered Bcl-x mRNA splicing in C6 glioma cells (data not shown). Furthermore, primary cortical neurons treated with C2ceramide, staurosporine, or oxygen-glucose deprivation demonstrated similar changes in $\mathrm{Bcl}-\mathrm{x}$ splicing, decreasing $\mathrm{Bcl}-\mathrm{x}_{\mathrm{L}}$ while increasing Bcl- $\mathrm{x}_{\mathrm{S}}$ (Fig. 1G). These data suggest that reciprocal Bcl-x alternative splice changes occur widely in neural cells induced by a variety of apoptotic stimuli.

Though overexpression of $\mathrm{Bcl}-\mathrm{x}_{\mathrm{S}}$ results in cell death in many in vitro paradigms (Lindenboim et al., 2001; Mitra et al., 2001), the converse experiment (i.e., the effect of selective decrease of endogenous $\mathrm{Bcl}-\mathrm{x}_{\mathrm{S}}$ on cell death) has never been performed. We designed an shRNA to selectively knock down Bcl- $\mathrm{x}_{\mathrm{S}}$ expression by targeting the Bcl- $\mathrm{x}_{\mathrm{S}} 5^{\prime}$ splice site (Fig. $2 A$ ). Knockdown resulted in a $>75 \%$ decrease in Bcl- $\mathrm{x}_{\mathrm{S}}$ mRNA and protein without altering Bcl- $\mathrm{x}_{\mathrm{L}}$ levels (Fig. $2 B$ ). This knockdown resulted in the attenuation of cell death induced by $\mathrm{C} 2$ (Fig. $2 \mathrm{C}$ ), indicating a critical role for $\mathrm{Bcl}-\mathrm{x}_{\mathrm{S}}$ in apoptosis.

\section{CUGBP1 regulates Bcl-x splicing and subsequent cell death}

Because Bcl- $\mathrm{x}_{\mathrm{L}}$ and $\mathrm{Bcl}-\mathrm{x}_{\mathrm{S}}$ are both critical regulators of apoptosis, the modulation of Bcl-x alternative splicing is likely to have profound effects on cell death. To elucidate cis-regulatory elements influencing $\mathrm{Bcl}-\mathrm{x}$ pre-mRNA alternative splicing, a rat $b c l-x$ minigene was constructed (Fig. 3A). Transfection of this minigene into both HeLa and C6 glioma cells (to ensure that effects were not cell-line-specific) resulted in the generation of $\mathrm{Bcl}-\mathrm{x}_{\mathrm{L}}$ and Bcl- $\mathrm{x}_{\mathrm{S}}$ minigene-specific transcripts (Fig. $3 A$ ). A series of progressively larger deletions within intron 2 were created to identify critical cis-regulatory sequences near the $\mathrm{Bcl}-\mathrm{x}_{\mathrm{L}} 5^{\prime}$ splice site. The serial deletions resulted in changes in the ratio of $\mathrm{Bcl}-\mathrm{x}_{\mathrm{L}} / \mathrm{Bcl}-\mathrm{x}_{\mathrm{S}}$ mRNA (Fig. $3 B$ ). We decided to pursue the non- overlapping deletion between D4 and D5 (a 22-bp segment) because of its dramatic effect on alternative splicing (favoring $\mathrm{Bcl}-\mathrm{x}_{\mathrm{S}}$ expression) and its close proximity to the $\mathrm{Bcl}-\mathrm{x}_{\mathrm{L}} 5^{\prime}$ splice site. Isolated deletion of this 22-bp sequence confirmed the importance of this sequence in regulating Bcl-x alternative splicing, demonstrating dramatic shifts toward $\mathrm{Bcl}-\mathrm{x}_{\mathrm{S}}$ expression (Fig. 3C). Further analysis of the deleted sequence revealed two adjacent UG-rich sequences. Point mutations in the proximal UG motif resulted in a threefold decrease in the $\mathrm{Bcl}-\mathrm{x}_{\mathrm{L}} / \mathrm{Bcl}-\mathrm{x}_{\mathrm{S}}$ ratio, while double mutations in both motifs resulted in a similar decrease in the ratio (Fig. $3 D$ ), indicating the importance of UG motifs in Bcl-x splice site selection. In addition to the UG-rich element, we identified two other intronic splicing enhancer consensus sequences between bp 296 and 1508 (Fig. 3B). One of the consensus sequences (GGGGG) is known to bind heterogeneous nuclear ribonucleoproteins (hnRNP $F / H$ ), while the other (UGCAUG) binds to the Fox $1 / 2$ family. Further investigation is needed to explore the role of these factors in the regulation of $\mathrm{Bcl}-\mathrm{x}$ splicing.

The UG-rich motifs in intron 2 constitute a consensus binding sequence for a family of RNA binding proteins known as the CELF (CUG-BP and ETR-3-like factor) family, which is known to regulate alternative pre-mRNA splicing (Barreau et al., 2006; Marquis et al., 2006). To identify trans-regulatory factors binding to this UG-rich motif, RNA EMSAs were performed. OP cell nuclear extracts were incubated with radiolabeled oligonucleotides containing the UG-rich motif, cross-linked by UV exposure, and electrophoresed. Two bands migrating at $\sim 50 \mathrm{kDa}$ were identified and eliminated when incubated with an excess cold RNA probe indicating binding specificity (Fig. $4 A$ ). The EMSA was probed with antibodies to two members of the CELF family, CUGBP1 (CUG-binding protein 1) and ETR-3 (elav-type ribonucleoprotein 3 ), to identify specific proteins in the EMSA complex. Binding activity was eliminated with the CUGBP1 antibody but not the ETR-3 antibody (Fig. 4B). A mutated probe with double point mutations in the UG motifs (similar to that used in Fig. 3D) lacked RNA binding activity, confirming specificity of binding (Fig. 4C). Calf intestinal alkaline phosphatase treatment eliminated the binding activity, suggesting that activity was regulated by phosphorylation (Fig. 4D). These findings suggest that CUGBP1 specifically binds to the UG-rich motif near the $5^{\prime}$ splice site of $\mathrm{Bcl}-\mathrm{x}_{\mathrm{L}}$, and that its binding is regulated by phosphorylation. In agreement, the molecular weight of the factor in the UV cross-linking experiments ( $49-51 \mathrm{kDa}$; Fig. $4 \mathrm{~A}$ ) is identical to the known molecular weights of CUGBP1 (hyper- and hypophosphorylated isoforms) (Timchenko et al., 1996).

Next, we examined CUGBP1 subcellular expression using immunocytochemistry, subcellular fractionation, and Western blotting. Under basal conditions, CUGBP1 was found prominently in the nucleus; however, after $\mathrm{C} 2$ treatment nuclear CUGBP1 content decreased over time (Fig. $5 A, F$ ). After $24 \mathrm{~h}$, CUGBP1 immunoreactivity could be detected in only a few nuclei (Fig. 5A-C). Double-labeling with CUGBP1 immunostaining and TUNEL showed that virtually all of the TUNEL $(+)$ cells had exclusive cytoplasmic CUGBP1 localiza- 
A
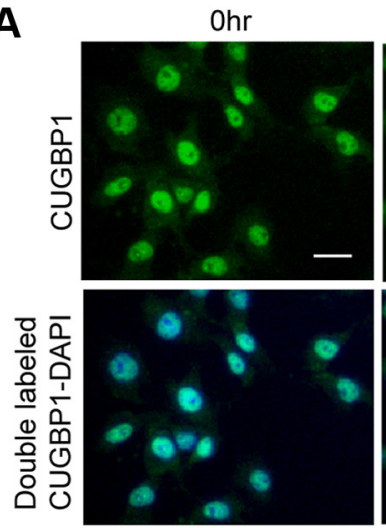

B
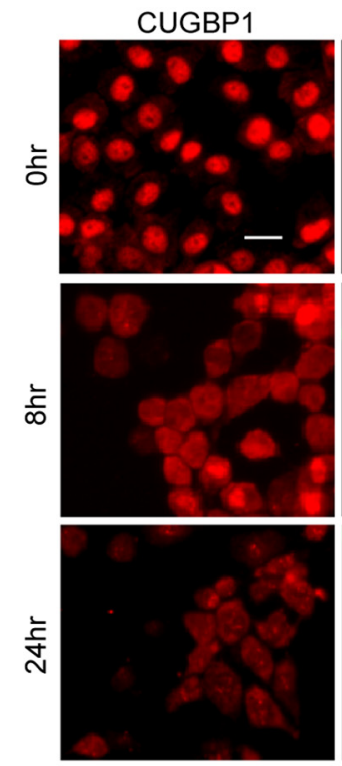

$\mathbf{E}$

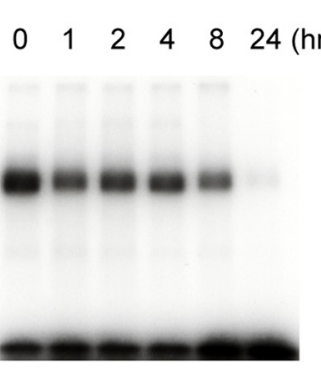

$\mathbf{F}$
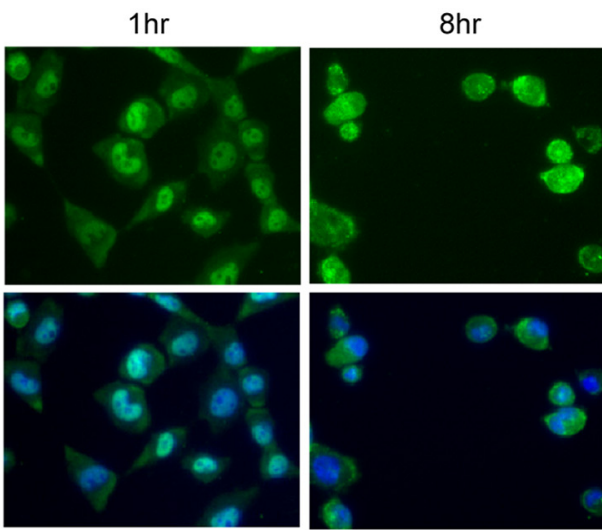

TUNEL
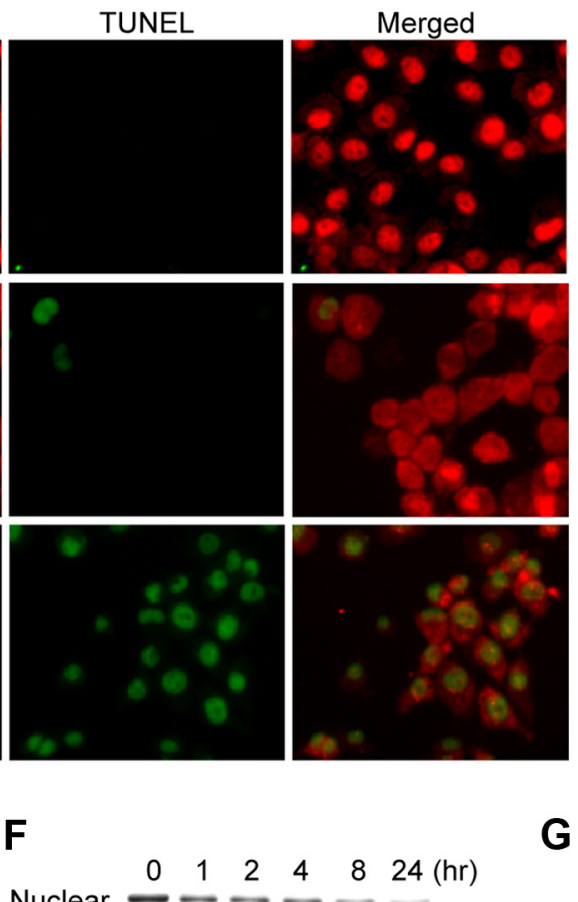

$\mathbf{G}$
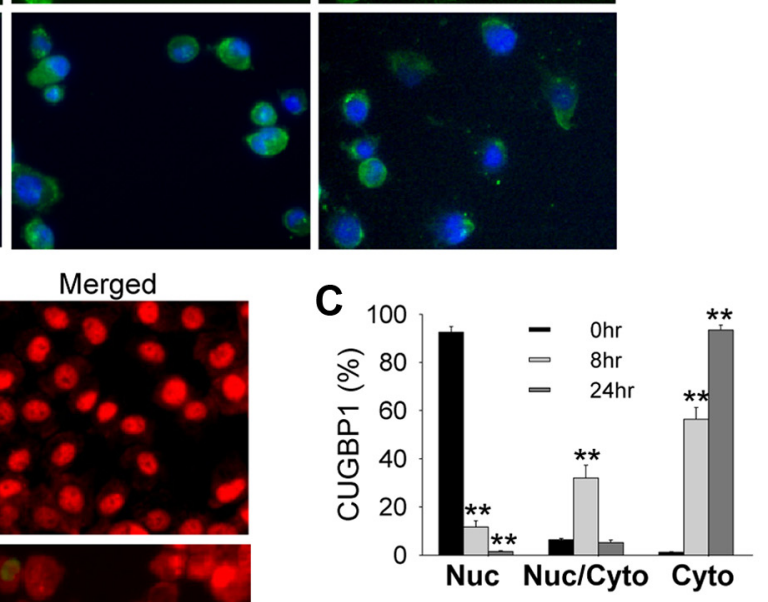

D

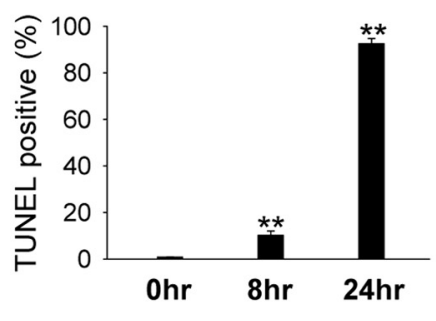

$24 \mathrm{hr}$
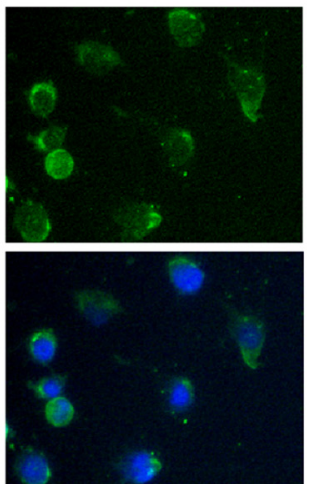

Cytosol $==$
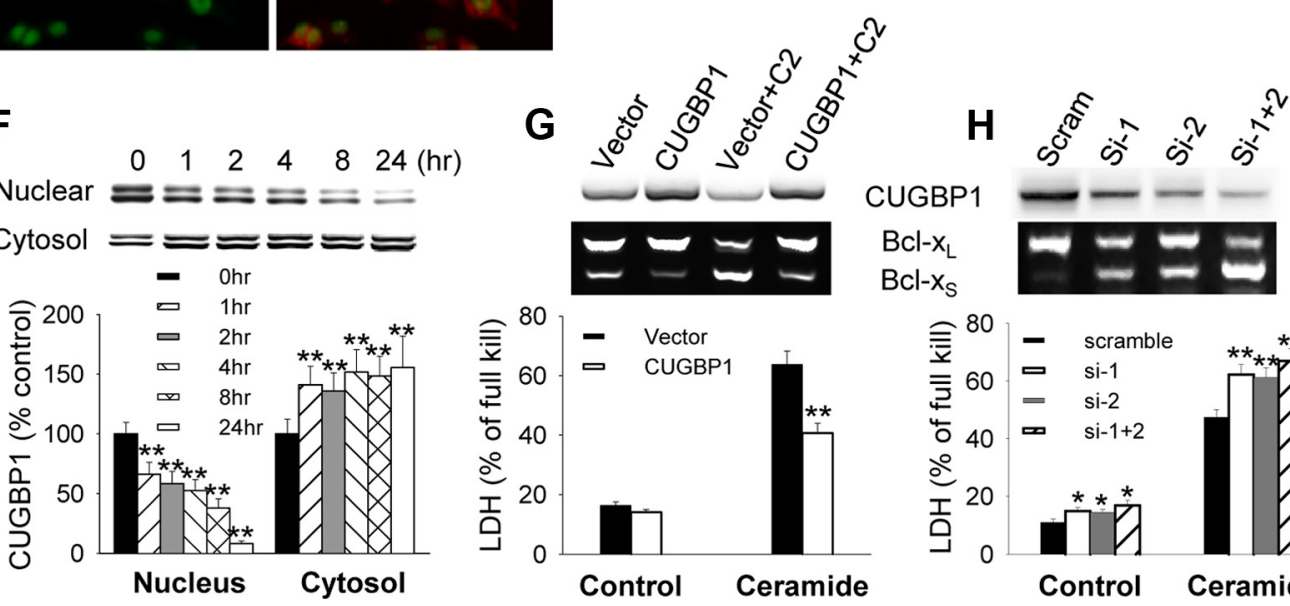

Figure 5. Alterations in subcellular CUGBP1 distribution affect Bcl-x splicing and cell death. OP cells were treated with C2-ceramide (50 $\mu \mathrm{M})$ for varying times as indicated. $A$, Immunocytochemistry reveals that nuclear CUGBP1 rapidly decreases after treatment with C2-ceramide (top, CUGBP1 immunostaining, green; bottom, overlay of CUGBP1 immunostaining, green, and DAPI staining, blue). B, Double-labeling with CUGBP1 immunostaining (red) and TUNEL (green) after (2-ceramide treatment demonstrates that virtually all TUNEL $(+)$ cells had cytoplasmic CUGBP1. $\boldsymbol{C}, \boldsymbol{D}$, Subcellular localization of CUGBP1 $(\boldsymbol{C})$ and TUNEL $(+)$ cells $(\boldsymbol{D})$ were quantified and expressed as mean \pm SE. from three independent experiments. ${ }^{* *} p<0.01$ compared to $0 \mathrm{~h}$ control (ANOVA with post hoc Tukey's test). Nuc, Nucleus; Cyto, cytosol. $E$, Nuclear extracts from OP cells after ceramide treatment demonstrate decreased UG-rich RNA binding using EMSA. $\boldsymbol{F}$, Western blots from subcellular fractions of OP cells after ceramide treatment (top) confirm the decrease in nuclear CUGBP1. Blots were quantified by densitometry, normalized to actin, and expressed as mean \pm SE from three independent experiments (bottom), ${ }^{* *} p<0.01$ compared to nuclear or cytosol control (ANOVA with post hoc Tukey's test). G, OP cells were transfected with CUGBP1 or vector constructs. H, CUGBP1 was knocked down using RNAi. At $24 \mathrm{~h}$ post-transfection, ceramide was added to the cell culture for an additional 16h. Overexpression and knockdown of CUGBP1 were verified by Western blot (top), alternatively spliced BCl-x forms were determined by RT-PCR (middle panel), and cell death was assessed by LDH assay (bottom). ${ }^{*} p<0.05$ si-CUGBP1 versus si-scramble, ${ }^{* *} p<0.01$ CUGBP1 construct versus vehicle construct, or si-CUGBP1+ ceramide versus si-scramble + ceramide (ANOVA with post hoc Tukey's test). Scale bars, $20 \mu \mathrm{m}$. 


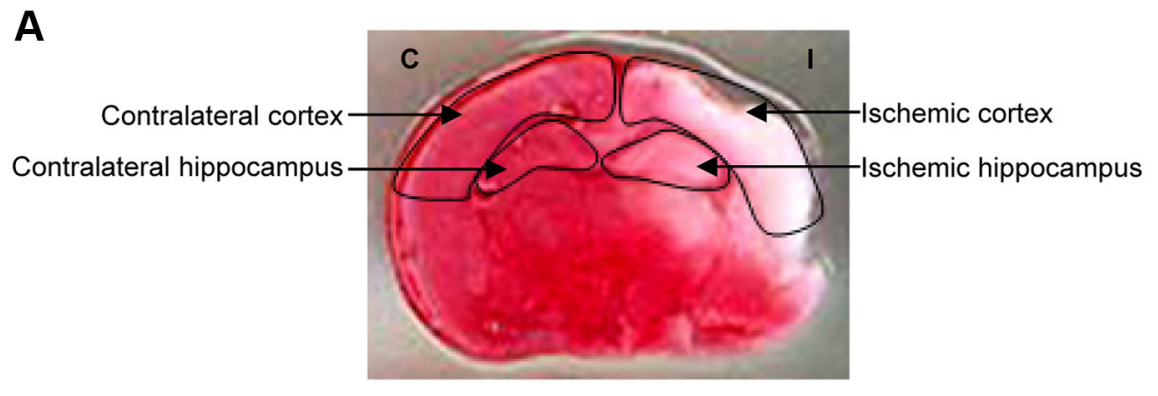

B
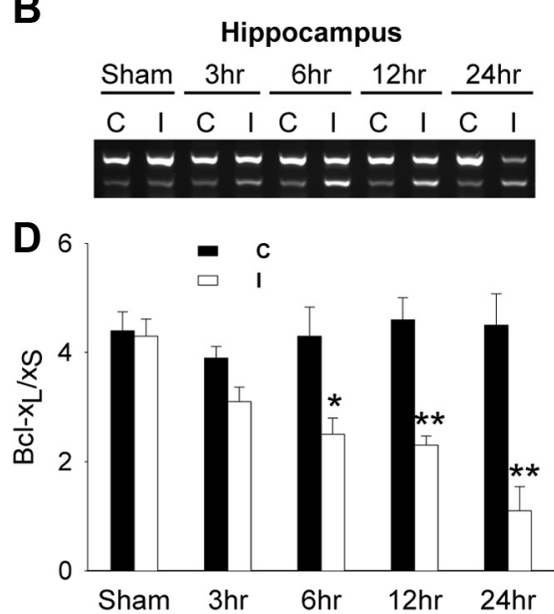

$\mathbf{F}$
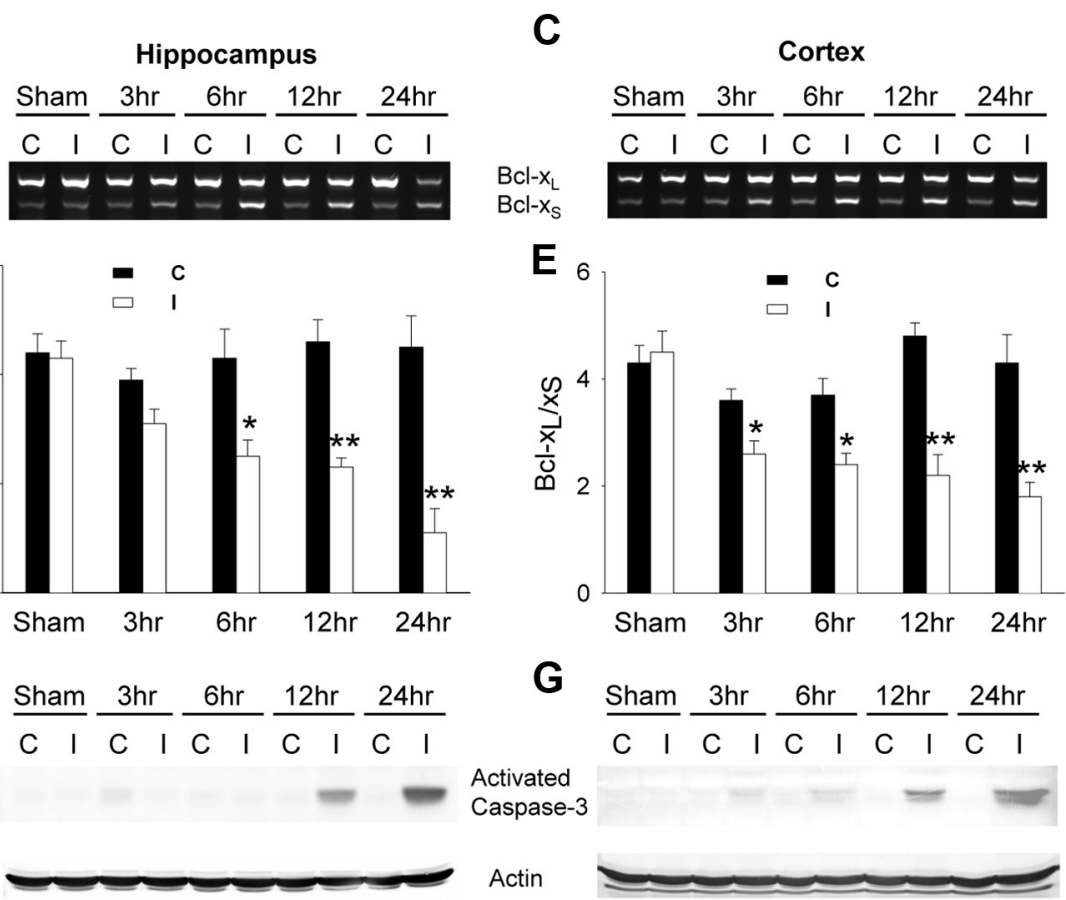

G

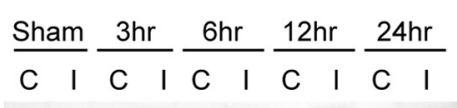

Activated

Caspase-3

Actin

Figure 6. Neonatal hypoxia-ischemia alters Bcl-x alternative splicing. P7 rats underwent unilateral carotid artery ligation and exposure to hypoxia for $2.5 \mathrm{~h}$ and were killed at varying times $(3,6,12$, and $24 \mathrm{~h})$ after hypoxia. $A$, The infarcted area of a representative brain section is shown by TTC staining $24 \mathrm{~h}$ after $\mathrm{H}-\mathrm{I}$. Arrows indicate contralateral (C) or ischemic (I) hippocampus and cortex used for RNA extraction. $\boldsymbol{B}$, C, Total RNA was extracted and analyzed by RT-PCR for alternative splicing of $B C l-x$. A representative agarose gel of the RT-PCR products from hippocampus $(\boldsymbol{B})$ or cortex $(\boldsymbol{C})$ is shown (C, Contralateral hemisphere; I, ischemic hemisphere). $\boldsymbol{D}, \boldsymbol{E}$, Mean value \pm SE of the $B C l-x_{L} /$ $\mathrm{BCl}-\mathrm{x}_{\mathbf{S}}$ ratio is from hippocampus $(\boldsymbol{D})$ and cortex $(\boldsymbol{E})$ from at least 5 animals per group. ${ }^{*} p<0.05,{ }^{* *} p<0.01$ ischemic versus contralateral (ANOVA with post hoc Tukey's test). $\boldsymbol{F}, \mathbf{G}$, Western blots were performed to measure activated caspase-3 from hippocampal $(\boldsymbol{F})$ and cortical (G) extracts (blots are representative of two independent replicates).

tion, and TUNEL $(-)$ cells showed progressively more cytoplasmic CUGBP1 with time (Fig. 5B-D). Consistent with these findings, nuclear CUGBP1 RNA-binding activity decreased rapidly after C2 treatment (Fig. 5E). To further examine its regulatory role in Bcl-x splicing following injury, CUGBP1 was overexpressed in OP cells. Compared to pcDNA3.1, ectopic expression of CUGBP1 increased $\mathrm{Bcl}-\mathrm{x}_{\mathrm{L}}$ and decreased $\mathrm{Bcl}-\mathrm{x}_{\mathrm{S}}$, resulting in decreased vulnerability to $\mathrm{C} 2$ treatment (Fig. 5G). Furthermore, knockdown of CUGBP1 using siRNA resulted in a decrease in the $\mathrm{Bcl}-\mathrm{x}_{\mathrm{L}} / \mathrm{Bcl}-\mathrm{x}_{\mathrm{S}}$ ratio and an increase in $\mathrm{C} 2$-induced cell death (Fig. $5 H$ ). These data indicate that CUGBP1 regulates $\mathrm{Bcl}-\mathrm{x}$ pre-mRNA splicing and thereby regulates cell death.

\section{Effects of Bcl-x alternative splicing in}

neonatal hypoxia-ischemia

Unilateral $\mathrm{H}-\mathrm{I}$ in neonatal rats induces well characterized brain injury within the ipsilateral cortex and hippocampus (Fig. 6A) with prominent features of apoptosis (Pulera et al., 1998; Nakajima et al., 2000). To determine whether $\mathrm{H}-\mathrm{I}$ resulted in alterations in Bcl-x pre-mRNA splicing, $\mathrm{P} 7$ rats subjected to unilateral
$\mathrm{H}-\mathrm{I}$ were killed at various times after $\mathrm{H}-\mathrm{I}$. Within 3-6 h after $\mathrm{H}-\mathrm{I}$, the $\mathrm{Bcl}-\mathrm{x}_{\mathrm{L}} / \mathrm{Bcl}-\mathrm{x}_{\mathrm{S}}$ ratio was decreased in the ischemic hippocampus and cortex compared to the contralateral side (Fig. 6B-E). Further decreases in the $\mathrm{Bcl}-\mathrm{x}_{\mathrm{L}} / \mathrm{Bcl}-\mathrm{x}_{\mathrm{S}}$ ratio were observed up to $24 \mathrm{~h}$ after $\mathrm{H}-\mathrm{I}$. Sham operated rats demonstrated no changes in this ratio (between hemispheres). In both hippocampus and cortex, caspase-3 activation occurred at later time points (12 and $24 \mathrm{~h}$ ), suggesting that the Bcl-x pre-mRNA splicing changes preceded this downstream apoptotic event (Fig. 6F, G).

To test whether knocking down $\mathrm{Bcl}-\mathrm{x}_{\mathrm{S}}$ results in neuroprotection in neonatal $\mathrm{H}-\mathrm{I}$ brain injury, a recombinant lentiviral vector carrying $\mathrm{Bcl}-\mathrm{x}_{\mathrm{S}}$ shRNA was directly injected into left anterior hippocampus of the newborn rat. An EGFP gene driven by a PGK promoter in the same vector demonstrated robust fluorescence in the hippocampus 1 week after injection (Fig. 7A), indicating successful LV-mediated gene transfer. At P7, animals were subjected to unilateral $\mathrm{H}-\mathrm{I}$, and killed 1 week later. Compared to scrambled shRNA, the $\mathrm{Bcl}-\mathrm{x}_{\mathrm{S}}$ shRNA decreased $\mathrm{Bcl}-\mathrm{x}_{\mathrm{S}}$ without significantly altering $\mathrm{Bcl}-\mathrm{x}_{\mathrm{L}}$ levels in the LV-injected hippocampus (Fig. 7B). As expected, both $\mathrm{Bcl}-\mathrm{x}_{\mathrm{L}}$ and $\mathrm{Bcl}-\mathrm{x}_{\mathrm{S}}$ levels did not change in the cortex (Fig. 7C), demonstrating the anatomic specificity of LV-mediated shRNA knockdown. H-I resulted in significant brain tissue loss both in the hippocampus and cortex when assessed 1 week after $\mathrm{H}-\mathrm{I}$ (Fig. 7D-F). Bcl- $\mathrm{x}_{\mathrm{S}}$ shRNA reduced tissue loss by $47 \%$ in the ischemic hippocampus compared to the scrambled shRNA group; as expected, cortical loss was not significantly different between the two groups (Fig. $7 D-F$ ). Thus, $\mathrm{Bcl}-\mathrm{x}_{\mathrm{S}}$-specific knockdown protected brain tissue against $\mathrm{H}-\mathrm{I}$-induced cell death, indicating its important role in neural cell injury independent of $\mathrm{Bcl}-\mathrm{x}_{\mathrm{L}}$ effects.

\section{Hypoxia-ischemia alters CUGBP1 expression concomitant with Bcl-x splicing changes}

We next sought to determine whether CUGBP1 expression and subcellular localization were altered after neonatal H-I. RNA EMSA showed a marked decrease of CUGBP1 binding activity in cortical nuclear extracts $3 \mathrm{~h}$ after $\mathrm{H}-\mathrm{I}$ compared to the contralateral hemisphere and sham controls (Fig. $8 \mathrm{~A}$ ). These results were confirmed by cell fractionation/Western blot and immunohistochemistry that demonstrated reduced CUGBP1 expression in nuclei (Fig. $8 B, C, E$ ). The fractionation experiments did not show changes in cytosolic levels of CUGBP1, although the immunostaining showed slightly higher levels in the cytoplasm after $\mathrm{H}-\mathrm{I}$ (Fig. $8 B, D, E)$.

\section{Discussion}

Given the critical role of $\mathrm{Bcl}-\mathrm{x}_{\mathrm{L}}$ in cell viability in the developing and adult nervous system, it is not surprising that alternative 
A

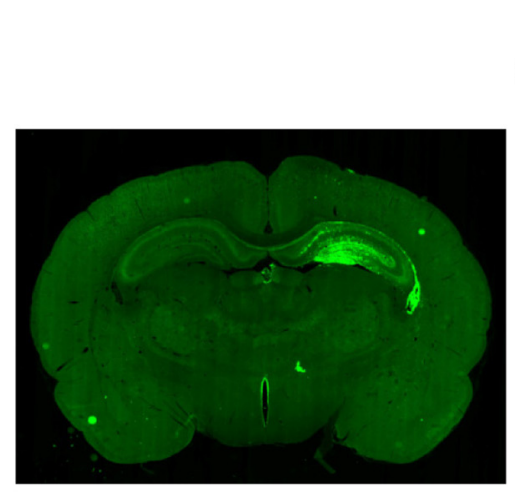

D

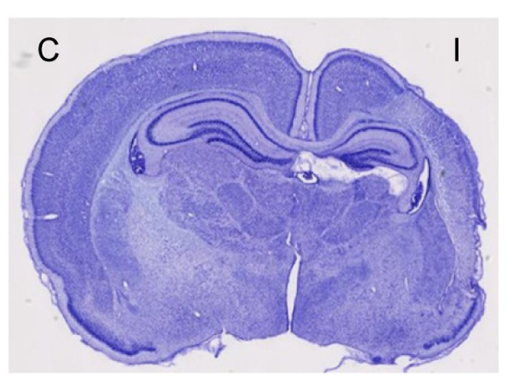

B

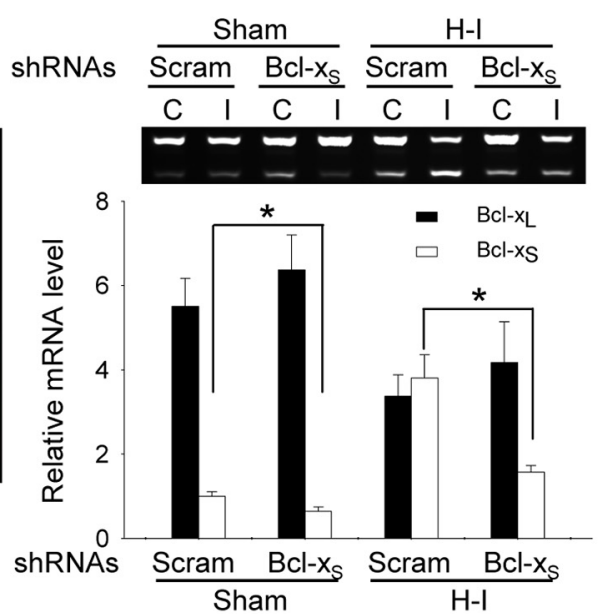

E

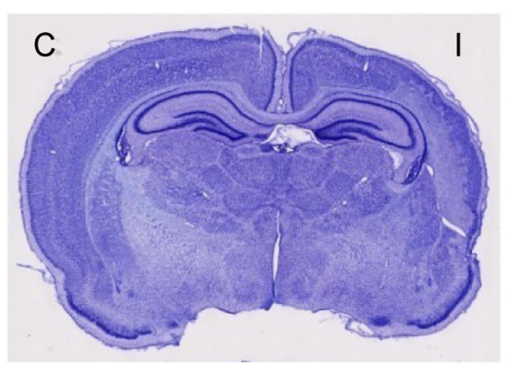

C

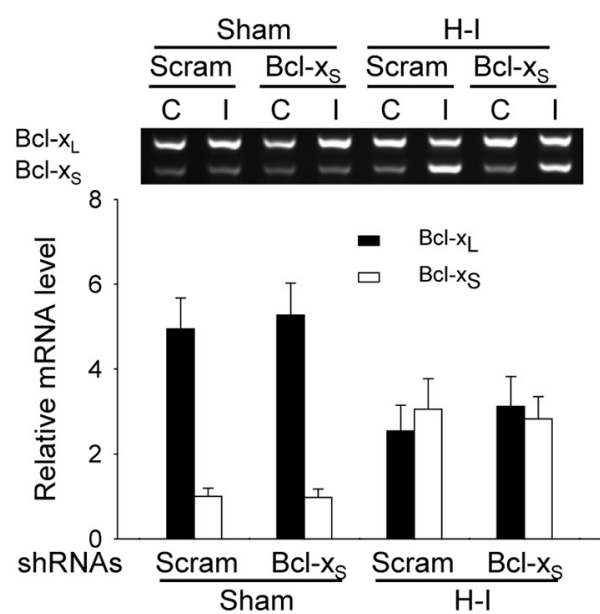

F

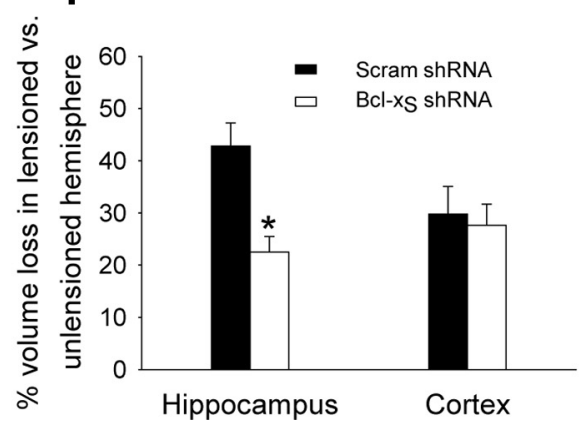

Figure 7. Knockdown of $B C l-x_{S}$ attenuates brain injury following $\mathrm{H}-\mathrm{I}$. Lentiviral vectors carrying $\mathrm{Bcl}-\mathrm{x}_{\mathrm{S}}$ shRNA or scrambled (Scram) shRNA were injected into the left hippocampus of $\mathrm{PO}$ rats. $\boldsymbol{A}$, A representative example of gene transfer is shown by detecting EGFP expression 1 week after injection. $B, C$, Animals were subjected to $H-I$ at $P 7$ and killed at $P 14$. $B C l-x_{L}$ and $B C l-x_{S} m R N A$ levels from the hippocampus $(\boldsymbol{B})$ and cortex $(\boldsymbol{C})$ were determined by RT-PCR (mean \pm SE from 5 animals). $\boldsymbol{D}, \boldsymbol{E}$, Representative cresyl-violet-stained brain sections from rats from each group ( $\boldsymbol{D}$, scrambled shRNA: $n=17 ; \boldsymbol{E}, \mathrm{BCl}-\mathrm{x}_{S}$ shRNA: $n=18$ ) are shown. C, Contralateral hemisphere; I, ischemic hemisphere. $\boldsymbol{F}, B_{C}-x_{S}$ shRNA significantly reduced tissue loss in hippocampus where shRNA was targeted but not cortex (mean $\pm \mathrm{SE}$; ${ }^{*} p<0.01 \mathrm{BCl}-\mathrm{x}_{\mathrm{S}}$ shRNA versus scrambled shRNA).

splicing of Bcl-x pre-mRNA is tightly regulated under normal physiological conditions. In this study, we demonstrate the importance of splicing regulation in pathological CNS injury in vivo. $\mathrm{Bcl}-\mathrm{x}$ splicing is altered after neonatal $\mathrm{H}-\mathrm{I}$, resulting in increased expression of $\mathrm{Bcl}-\mathrm{x}_{\mathrm{S}}$ relative to $\mathrm{Bcl}-\mathrm{x}_{\mathrm{L}}$. These splicing changes occurred earlier than downstream apoptotic events such as caspase- 3 activation and DNA fragmentation, suggesting an upstream regulatory role. Moreover, specifically knocking down the $\mathrm{Bcl}-\mathrm{x}_{\mathrm{S}}$ isoform (with concomitant changes in Bcl-x isoform ratios) before $\mathrm{H}-\mathrm{I}$ in neonatal rats resulted in attenuation of brain injury. Previous studies have shown that overexpression of $\mathrm{Bcl}-\mathrm{x}_{\mathrm{L}}$ in similar H-I models also attenuates brain injury (Parsadanian et al., 1998; Yin et al., 2006). Collectively, these data indicate that the ratio of $\mathrm{Bcl}-\mathrm{x}$ isoforms plays a critical role in brain injury and suggest that the coordinate control of both isoforms via splicing regulation may have additive or synergistic effects.

The pre-mRNA splicing machinery is extremely complex, involving numerous cis-acting splicing sequences, trans-acting splicing factors, interactions with transcription regulation, and mRNA export (Chen and Manley, 2009). To identify cis-elements and trans-factors, we created a Bcl-x minigene. Successive deletions within intron 2 resulted in the identification of several splicing enhancers and suppressors with profound effects on the ratio of $\mathrm{Bcl}-\mathrm{x}_{\mathrm{L}} / \mathrm{Bcl}-\mathrm{x}_{\mathrm{S}}$ mRNA (Fig. 3). A UG-rich element located downstream of the $\mathrm{Bcl}-\mathrm{x}_{\mathrm{L}} 5^{\prime}$ splicing site was identified as an important sequence for altering splicing, and CUGBP1 was found to specifically bind to this sequence. In vitro and in vivo studies revealed that nuclear CUGBP1 content was significantly reduced after apoptotic stimulation. Furthermore, overexpression of CUGBP1 in vitro increased the $\mathrm{Bcl}-\mathrm{x}_{\mathrm{L}} / \mathrm{Bcl}-\mathrm{x}_{\mathrm{S}}$ ratio, while RNAi-mediated knockdown decreased the ratio.

CUGBP1 was first identified as a factor binding to pathologically expanded $(\mathrm{CUG})_{\mathrm{n}}$ repeats in dystrophia myotonin protein kinase (DMPK) mRNA found in patients with myotonic dystrophy (Timchenko et al., 1996; Roberts et al., 1997). In this disorder, pathogenesis is related in part to an increase in expression of CUGBP1, resulting in disrupted regulation of alternative splicing, mRNA translation, and mRNA stability (Philips et al., 1998; Ranum and Cooper, 2006). CUGBP1 has been reported to regulate alternative splicing of a variety of genes (Philips et al., 1998; Gromak et al., 2003; Dansithong et al., 2005; Ho et al., 2005) via binding to UG or UGU motifs (Faustino and Cooper, 2005; Marquis et al., 2006). It is post-translationally regulated by phosphorylation that alters RNA binding activity, increases nuclear localization, and enhances splicing activity (Roberts et al., 1997). Our findings of altered subcellular distribution and RNAbinding activity of CUGBP1 following $\mathrm{H}-\mathrm{I}$ are consistent with these known regulatory pathways. CUGBP1 ${ }^{-/-}$mice have been generated, but a significant proportion of the animals do not survive past the first few days of life. These animals display growth retardation and impaired fertility due to increased apoptosis of germ cells (Kress et al., 2007). Overexpression of CUGBP1 has 
A

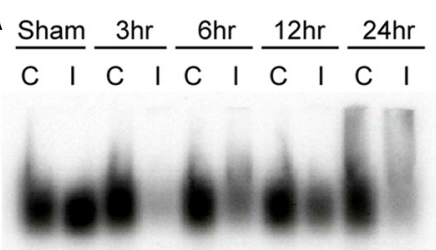

B

$$
\frac{\text { Sham }}{\text { C I C I C I C I C I }} \frac{3 \mathrm{hr}}{12 \mathrm{hr}} \frac{24 \mathrm{hr}}{\mathrm{Ch}}
$$
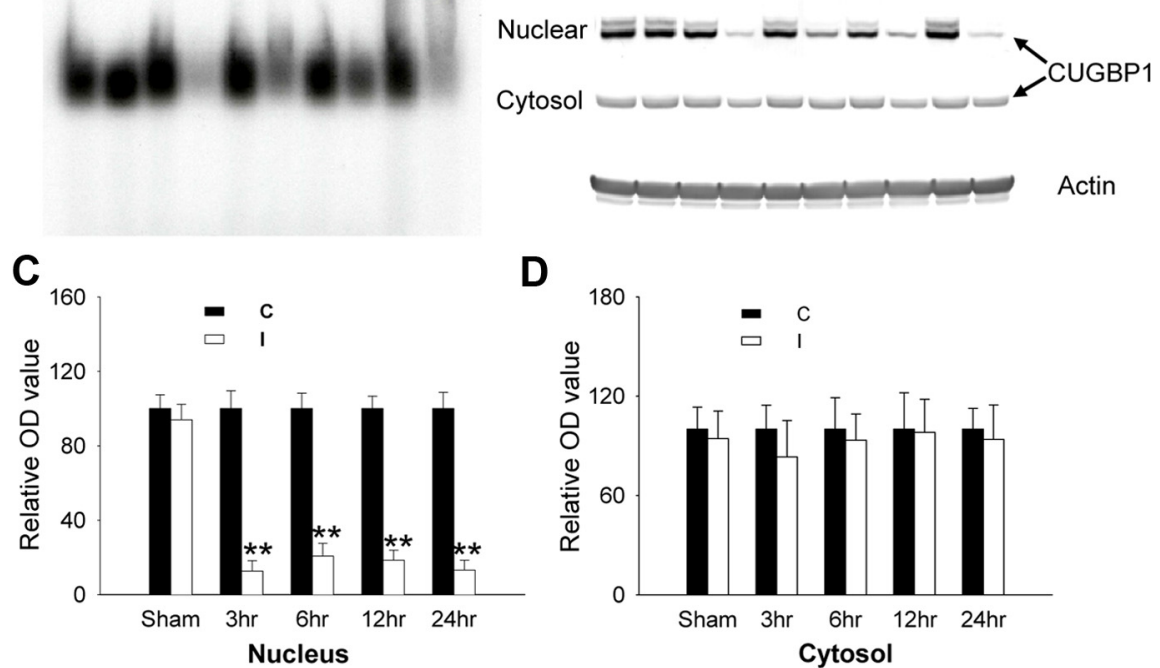

D

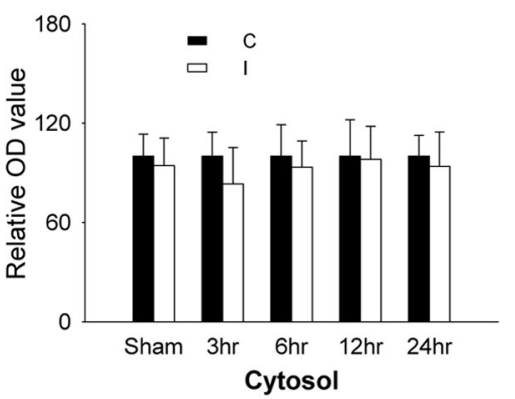

E
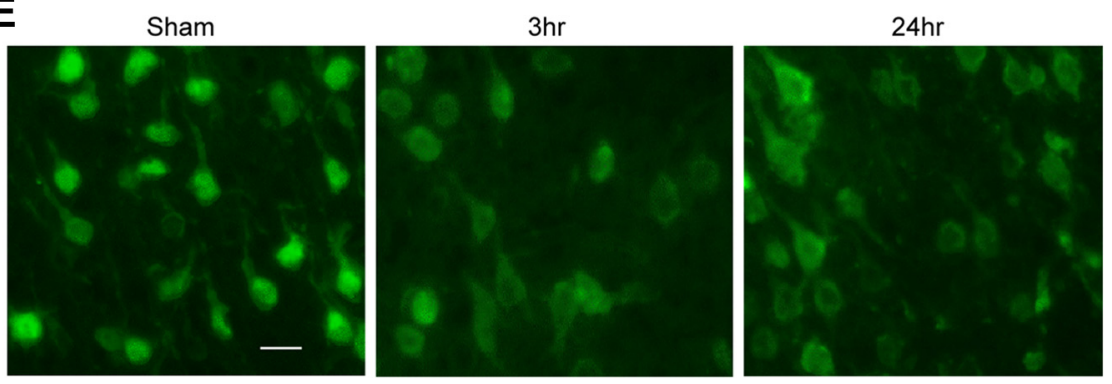

Figure 8. Alterations in subcellular CUGBP1 localization after H-I. $A$, Cortical nuclear extracts $(5 \mu \mathrm{g})$ show decreased binding to UG-rich RNA probes after $\mathrm{H}-\mathrm{I}$ measured via EMSA. $\boldsymbol{B}$ - $\boldsymbol{D}$, Cortical nuclear extracts $(5 \mu \mathrm{g})$ or cytosolic extracts $(20 \mu \mathrm{g})$ were subjected to Western blot to measure CUGBP1 levels after $\mathrm{H}-\mathrm{I}$, quantified by densitometry, and normalized to actin (B) (mean \pm SE of three independent experiments, $C, D)$. C, Contralateral hemisphere; I, ischemic hemisphere. ${ }^{*} p<0.01$ ischemic vs contralateral nuclear extracts (ANOVA with post hoc Tukey's test). $\boldsymbol{E}$, The intracellular localization of CUGBP1 in rat cortex was determined by immunostaining in sham control, 3 and $24 \mathrm{~h}$ after $\mathrm{H}-\mathrm{I}$. Scale bar, $20 \mu \mathrm{m}$.

been shown to suppress the rCGG-induced neurodegeneration in a transgenic Drosophila model of Fragile X-associated tremor/ ataxia syndrome (FXTAS) (Sofola et al., 2007), adding support to a possible role for CUGBP1 in cell death. In the current study, we report a direct link between CUGBP1 and Bcl-x pre-mRNA alternative splicing, with a resultant impact on apoptosis.

Though targeting regulators of pre-mRNA splicing may result in wide-spread changes in RNA splicing, further study might elucidate a target that specifically regulates cell death pathways. Indeed, several studies have shown that "master switch" splicing regulators may coordinately regulate specific unified functions such as synapse-interacting proteins encoded by Nova RNA targets (Ule et al., 2005). Because of the antagonistic activities of the two Bcl-x isoforms, the splicing machinery serves as an attractive therapeutic target in which a single manipulation may coordinately alter the expression of both pro- and anti-apoptotic proteins. Several other apoptotic genes appear to undergo alternative splicing, resulting in mRNA isoforms with antagonistic roles, such as Mcl-1, caspase- 2 and -9 , and adaptor proteins Apaf- 1 and IG20 (Wang et al., 1994; Jiang et al., 1998; Seol and Billiar, 1999; Bae et al., 2000; Bingle et al., 2000; Al-Zoubi et al., 2001; Efimova et al., 2004).

In summary, through both in vitro and in vivo neural injury models, we have found that regulation of Bcl-x alternative splic- ing modulates neural cell death. Our results suggest that alternative splicing may be an important regulatory mechanism for apoptosis after acute neurological injury, and that splicing regulators may be potential targets for attenuating CNS injury.

\section{References}

Al-Zoubi AM, Efimova EV, Kaithamana S, Martinez O, El-Idrissi Mel-A, Dogan RE, Prabhakar BS (2001) Contrasting effects of IG20 and its splice isoforms, MADD and DENN-SV, on tumor necrosis factor alpha-induced apoptosis and activation of caspase- 8 and -3 . J Biol Chem 276:47202-47211.

Back SA, Han BH, Luo NL, Chricton CA, Xanthoudakis S, Tam J, Arvin KL, Holtzman DM (2002) Selective vulnerability of late oligodendrocyte progenitors to hypoxia-ischemia. J Neurosci 22:455-463.

Bae J, Leo CP, Hsu SY, Hsueh AJ (2000) MCL-1S, a splicing variant of the antiapoptotic BCL-2 family member MCL-1, encodes a proapoptotic protein possessing only the $\mathrm{BH} 3$ domain. J Biol Chem 275:25255-25261.

Barreau C, Paillard L, Méreau A, Osborne HB (2006) Mammalian CELF/Bruno-like RNAbinding proteins: molecular characteristics and biological functions. Biochimie 88:515-525.

Bingle CD, Craig RW, Swales BM, Singleton V, Zhou P, Whyte MK (2000) Exon skipping in Mcl-1 results in a bcl-2 homology domain 3 only gene product that promotes cell death. J Biol Chem 275:22136-22146.

Cao G, Pei W, Ge H, Liang Q, Luo Y, Sharp FR, Lu A, Ran R, Graham SH, Chen J (2002) In vivo delivery of a Bcl-xL fusion protein containing the TAT protein transduction domain protects against ischemic brain injury and neuronal apoptosis. J Neurosci 22:5423-5431.

Chalfant CE, Rathman K, Pinkerman RL, Wood RE, Obeid LM, Ogretmen B, Hannun YA (2002) De novo ceramide regulates the alternative splicing of caspase 9 and Bcl-x in A549 lung adenocarcinoma cells: dependence on protein phosphatase-1. J Biol Chem 277:12587-12595.

Chen M, Manley JL (2009) Mechanisms of alternative splicing regulation: insights from molecular and genomics approaches. Nat Rev Mol Cell Biol 10:741-754. 19773805.

Dansithong W, Paul S, Comai L, Reddy S (2005) MBNL1 is the primary determinant of focus formation and aberrant insulin receptor splicing in DM1. J Biol Chem 280:5773-5780.

Efimova EV, Al-Zoubi AM, Martinez O, Kaithamana S, Lu S, Arima T, Prabhakar BS (2004) IG20, in contrast to DENN-SV (MADD splice variants) suppresses tumor cell survival, and enhances their susceptibility to apoptosis and cancer drugs. Oncogene 23:1076-1087.

Faustino NA, Cooper TA (2005) Identification of putative new splicing targets for ETR-3 using sequences identified by systematic evolution of ligands by exponential enrichment. Mol Cell Biol 25:879-887.

Gromak N, Matlin AJ, Cooper TA, Smith CW (2003) Antagonistic regulation of alpha-actinin alternative splicing by CELF proteins and polypyrimidine tract binding protein. Rna 9:443-456.

Han BH, Xu D, Choi J, Han Y, Xanthoudakis S, Roy S, Tam J, Vaillancourt J, Colucci J, Siman R, Giroux A, Robertson GS, Zamboni R, Nicholson DW, Holtzman DM (2002) Selective, reversible caspase-3 inhibitor is neuroprotective and reveals distinct pathways of cell death after neonatal hypoxic-ischemic brain injury. J Biol Chem 277:30128-30136.

Ho TH, Bundman D, Armstrong DL, Cooper TA (2005) Transgenic mice 
expressing CUG-BP1 reproduce splicing mis-regulation observed in myotonic dystrophy. Hum Mol Genet 14:1539-1547.

Holtzman DM, Sheldon RA, Jaffe W, Cheng Y, Ferriero DM (1996) Nerve growth factor protects the neonatal brain against hypoxic-ischemic injury. Ann Neurol 39:114-122.

Jiang ZH, Zhang WJ, Rao Y, Wu JY (1998) Regulation of Ich-1 pre-mRNA alternative splicing and apoptosis by mammalian splicing factors. Proc Natl Acad Sci U S A 95:9155-9160.

Kress C, Gautier-Courteille C, Osborne HB, Babinet C, Paillard L (2007) Inactivation of CUG-BP1/CELF1 causes growth, viability, and spermatogenesis defects in mice. Mol Cell Biol 27:1146-1157.

Lee JT, Xu J, Lee JM, Ku G, Han X, Yang DI, Chen S, Hsu CY (2004) Amyloid-beta peptide induces oligodendrocyte death by activating the neutral sphingomyelinase-ceramide pathway. J Cell Biol 164:123-131.

Lindenboim L, Borner C, Stein R (2001) Bcl-x(S) can form homodimers and heterodimers and its apoptotic activity requires localization of Bcl$\mathrm{x}(\mathrm{S})$ to the mitochondria and its $\mathrm{BH} 3$ and loop domains. Cell Death Differ 8:933-942.

Marquis J, Paillard L, Audic Y, Cosson B, Danos O, Le Bec C, Osborne HB (2006) CUG-BP1/CELF1 requires UGU-rich sequences for high-affinity binding. Biochem J 400:291-301.

Massiello A, Salas A, Pinkerman RL, Roddy P, Roesser JR, Chalfant CE (2004) Identification of two RNA cis-elements that function to regulate the $5^{\prime}$ splice site selection of Bcl-x pre-mRNA in response to ceramide. J Biol Chem 279:15799-15804.

Massiello A, Roesser JR, Chalfant CE (2006) SAP155 Binds to ceramideresponsive RNA cis-element 1 and regulates the alternative $5^{\prime}$ splice site selection of Bcl-x pre-mRNA. FASEB J 20:1680-1682.

McQuillen PS, Sheldon RA, Shatz CJ, Ferriero DM (2003) Selective vulnerability of subplate neurons after early neonatal hypoxia-ischemia. J Neurosci 23:3308-3315.

Mercatante DR, Bortner CD, Cidlowski JA, Kole R (2001) Modification of alternative splicing of $\mathrm{Bcl}$-x pre-mRNA in prostate and breast cancer cells. analysis of apoptosis and cell death. J Biol Chem 276:16411-16417.

Minn AJ, Boise LH, Thompson CB (1996) Bcl-x(S) antagonizes the protective effects of Bcl-x(L). J Biol Chem 271:6306-6312.

Mitra RS, Benedict MA, Qian D, Foreman KE, Ekhterae D, Nickoloff BJ, Nuñez G (2001) Killing of sarcoma cells by proapoptotic Bcl-X(S): role of the BH3 domain and regulation by Bcl-X(L). Neoplasia 3:437-445.

Motoyama N, Wang F, Roth KA, Sawa H, Nakayama K, Nakayama K, Negishi I, Senju S, Zhang Q, Fujii S (1995) Massive cell death of immature hematopoietic cells and neurons in Bcl-x-deficient mice. Science 267:1506-1510

Nakajima W, Ishida A, Lange MS, Gabrielson KL, Wilson MA, Martin LJ, Blue ME, Johnston MV (2000) Apoptosis has a prolonged role in the neurodegeneration after hypoxic ischemia in the newborn rat. J Neurosci 20:7994-8004.

Parsadanian AS, Cheng Y, Keller-Peck CR, Holtzman DM, Snider WD (1998) Bcl-xL is an antiapoptotic regulator for postnatal CNS neurons. J Neurosci 18:1009-1019.

Philips AV, Timchenko LT, Cooper TA (1998) Disruption of splicing regulated by a CUG-binding protein in myotonic dystrophy. Science 280:737-741.

Pulera MR, Adams LM, Liu H, Santos DG, Nishimura RN, Yang F, Cole GM,
Wasterlain CG (1998) Apoptosis in a neonatal rat model of cerebral hypoxia-ischemia. Stroke 29:2622-2630.

Ranum LP, Cooper TA (2006) RNA-mediated neuromuscular disorders. Annu Rev Neurosci 29:259-277.

Roberts R, Timchenko NA, Miller JW, Reddy S, Caskey CT, Swanson MS, Timchenko LT (1997) Altered phosphorylation and intracellular distribution of a (CUG)n triplet repeat RNA-binding protein in patients with myotonic dystrophy and in myotonin protein kinase knockout mice. Proc Natl Acad Sci U S A 94:13221-13226.

Seol DW, Billiar TR (1999) A caspase-9 variant missing the catalytic site is an endogenous inhibitor of apoptosis. J Biol Chem 274:2072-2076.

Sofola OA, Jin P, Qin Y, Duan R, Liu H, de Haro M, Nelson DL, Botas J (2007) RNA-binding proteins hnRNP A2/B1 and CUGBP1 suppress fragile X CGG premutation repeat-induced neurodegeneration in a Drosophila model of FXTAS. Neuron 55:565-571.

Taylor JK, Zhang QQ, Wyatt JR, Dean NM (1999) Induction of endogenous Bcl-xS through the control of Bcl-x pre-mRNA splicing by antisense oligonucleotides. Nat Biotechnol 17:1097-1100.

Timchenko LT, Miller JW, Timchenko NA, DeVore DR, Datar KV, Lin L, Roberts R, Caskey CT, Swanson MS (1996) Identification of a (CUG)n triplet repeat RNA-binding protein and its expression in myotonic dystrophy. Nucleic Acids Res 24:4407-4414.

Ule J, Ule A, Spencer J, Williams A, Hu JS, Cline M, Wang H, Clark T, Fraser C, Ruggiu M, Zeeberg BR, Kane D, Weinstein JN, Blume J, Darnell RB (2005) Nova regulates brain-specific splicing to shape the synapse. Nat Genet 37:844-852.

Villemaire J, Dion I, Elela SA, Chabot B (2003) Reprogramming alternative pre-messenger RNA splicing through the use of protein-binding antisense oligonucleotides. J Biol Chem 278:50031-50039.

Wang L, Miura M, Bergeron L, Zhu H, Yuan J (1994) Ich-1, an Ice/ced-3related gene, encodes both positive and negative regulators of programmed cell death. Cell 78:739-750.

Wiessner C, Allegrini PR, Rupalla K, Sauer D, Oltersdorf T, McGregor AL, Bischoff S, Böttiger BW, van der Putten H (1999) Neuron-specific transgene expression of $\mathrm{Bcl}-\mathrm{XL}$ but not $\mathrm{Bcl}-2$ genes reduced lesion size after permanent middle cerebral artery occlusion in mice. Neurosci Lett 268:119-122.

Xu J, Wu Y, He L, Yang Y, Moore SA, Hsu CY (1997) Regulation of cytokine-induced iNOS expression by a hairpin oligonucleotide in murine cerebral endothelial cells. Biochem Biophys Res Commun 235:394-397.

Xu J, He L, Ahmed SH, Chen SW, Goldberg MP, Beckman JS, Hsu CY (2000) Oxygen-glucose deprivation induces inducible nitric oxide synthase and nitrotyrosine expression in cerebral endothelial cells. Stroke 31:1744-1751.

Yin KJ, Lee JM, Chen SD, Xu J, Hsu CY (2002) Amyloid-beta induces Smac release via AP-1/Bim activation in cerebral endothelial cells. J Neurosci 22:9764-9770.

Yin W, Cao G, Johnnides MJ, Signore AP, Luo Y, Hickey RW, Chen J (2006) TAT-mediated delivery of Bcl-xL protein is neuroprotective against neonatal hypoxic-ischemic brain injury via inhibition of caspases and AIF. Neurobiol Dis 21:358-371.

Zhang SC, Ge B, Duncan ID (1999) Adult brain retains the potential to generate oligodendroglial progenitors with extensive myelination capacity. Proc Natl Acad Sci U S A 96:4089-4094. 